\title{
A Proposal for Positive Cooperativity in Anion-Cation Binding in Yttrium and Lutetium Complexes Based on o-Amino-Substituted Phenolate Ligands. On the Way to Coordination Polymers by Self-Assembly. Molecular Structures of [ClLu(OAr) $\left.{ }_{3} \mathrm{Na}\right](\mathrm{X}-\mathrm{ray})$ and $\left[\mathrm{CIY}\left(\mathrm{OAr}^{\prime}\right)_{3} \mathrm{Y}\left(\mathrm{OAr}^{\prime}\right)_{3} \mathrm{Na}\right]\left(\mathrm{X}\right.$-ray and ${ }^{89} \mathrm{Y}$-NMR)
}

\author{
Marinus P. Hogerheide, ${ }^{\dagger}$ Stéphanie N. Ringelberg, ${ }^{\dagger}$ David M. Grove ${ }^{\dagger}$ \\ Johann T. B. H. Jastrzebski, ${ }^{\dagger}$ Jaap Boersma, ${ }^{\dagger}$ Wilberth J. J. Smeets, \\ Anthony L. Spek, $*,, \&$ and Gerard van Koten $*, \dagger$ \\ Department of Metal-Mediated Synthesis, Debye Institute, and Laboratory of Crystal and \\ Structural Chemistry, Bijvoet Center for Biomolecular Research, Utrecht University, \\ Padualaan 8, $3584 \mathrm{CH}$ Utrecht, The Netherlands \\ Received May 22, $1995^{\otimes}$
}

\begin{abstract}
Unique hetero(poly)metallic complexes $\left[\mathrm{ClM}(\mathrm{OAr})_{3} \mathrm{Na}\right](\mathrm{M}=\mathrm{Lu}(\mathbf{3 a}), \mathrm{Y}(\mathbf{3 b}))$ and $\left[\mathrm{ClY}\left(\mathrm{OAr}^{\prime}\right)_{3} \mathrm{Y}\left(\mathrm{OAr}^{\prime}\right)_{3} \mathrm{Na}\right]$ (4) containing the bis $\left(\mathrm{OAr}=\mathrm{OC}_{6} \mathrm{H}_{2}\left(\mathrm{CH}_{2} \mathrm{NMe}_{2}\right)_{2}\right.$-2,6-Me-4) and mono $\left(\mathrm{OAr}^{\prime}=\mathrm{OC}_{6} \mathrm{H}_{4}\left(\mathrm{CH}_{2} \mathrm{NMe}_{2}\right)\right.$-2) $o$-aminosubstituted phenolate ligands have been synthesized and characterized by NMR $\left({ }^{1} \mathrm{H},{ }^{13} \mathrm{C}\right.$, and $\left.{ }^{89} \mathrm{Y}\right)$ and $\mathrm{X}$-ray structure determinations (3a and $\mathbf{4})$. Crystals of $\mathbf{3 a}$ are triclinic, space group $P \overline{1}$, with unit cell dimensions $a=$ 10.706(1) $\AA, b=14.099(2) \AA, c=18.882(3) \AA, \alpha=93.48(1)^{\circ}, \beta=99.49(1)^{\circ}, \gamma=108.72(11)^{\circ}$, and $Z=2$. The chlorine, lutetium, and sodium atoms in 3a lie on a pseudo-3-fold axis $\left(\angle \mathrm{Cl}-\mathrm{Lu} \cdots \mathrm{Na}=177.82(5)^{\circ}\right)$ around which the three phenolate ligands are arranged in such a way that a "propeller-like" molecule with screw-type chirality results. Crystals of $\mathbf{4}$ are triclinic, space group $P 1$, with unit cell dimensions $a=11.411$ (4) $\AA, b=$ 13.325(4) $\AA, c=13.599(4) \AA, \alpha=88.91(3)^{\circ}, \beta=65.44(2)^{\circ}, \gamma=72.77(3)^{\circ}$, and $Z=1$. In 4 the chlorine, the two yttrium and the sodium atoms lie on a pseudo-3-fold axis $\left(\mathrm{Cl}-\mathrm{Y}(1) \cdots \mathrm{Y}(2) \cdots \mathrm{Na}: \angle \mathrm{Cl}-\mathrm{Y} \cdots \mathrm{Y}=179.36(8)^{\circ}\right.$ and $\left.\angle \mathrm{Y} \cdots \mathrm{Y} \cdots \mathrm{Na}=178.38(10)^{\circ}\right)$ around which the six phenolate ligands are arranged in two shells of three ligands. One shell bridges the yttrium atoms in an asymmetric fashion, while the second shell bridges the second yttrium and the sodium atom, resulting in two shells of opposite screw-type chirality. ${ }^{1} \mathrm{H},{ }^{13} \mathrm{C}$, and ${ }^{89} \mathrm{Y}$ (for $\mathbf{3 b}$ and 4) NMR confirmed that the structures found for 3a and $\mathbf{4}$ in the solid state are retained in solution. For $\mathbf{4}^{89} \mathrm{Y}$ NMR showed two separate resonances (202.4 and $132.4 \mathrm{ppm}$ ), with ${ }^{2} J_{\mathrm{YY}}=0.4 \mathrm{~Hz}$. The formation of $\mathbf{3 a}$ and $\mathbf{3 b}$ is described as resulting from positive cooperativity in anion-cation bonding: coordination of chloride anion to a neutral metal tris(phenolate) leads to preorganization of available binding sites in the resulting anionic complex for the binding of the sodium cation. In $\mathbf{4}$ this cooperativity is the driving force for the self-assembly of an anionic bimetallic molecular structure with available, preorganized binding sites for the capture of the cation. A proposal is made to use these observations for the possible synthesis of new coordination polymers.
\end{abstract}

\section{Introduction}

Lanthanide and group 3 alkoxide complexes that are volatile and/or soluble in organic solvents have a great potential as precursors for the preparation of lanthanide containing oxide materials by either the MOCVD ${ }^{1}$ or the sol-gel technique. ${ }^{2}$ The

* To whom correspondence should be addressed.

$\dagger$ Debye Institute, Utrecht University.

$¥$ Bijvoet Center for Biomolecular Research.

$\S$ Address correspondence regarding the crystallography to this author.

${ }^{\otimes}$ Abstract published in Advance ACS Abstracts, January 1, 1996

(1) (a) Desu, S. B., Beach, D. B., Wessels, B. W., Gokoglu, S., Eds. MetalOrganic Chemical Vapor Deposition of Electronic Ceramics. Mater. Res. Soc. Symp. Proc. 1994, 335. (b) Bradley, D. C. Chem. Rev. 1989, 89, 1317. (c) Hubert-Pfalzgraf, L. G.; Massiani, M. C.; Papiernik, R.; Poncelet, O. J. Phys. Colloq. 1989, 50, C5-981. (d) Deacon, G. B.; MacKinnon, P.; Dickson, R. S.; Pain, G. N.; West, B. O. Appl. Organomet. Chem. 1990, 4, 439.

(2) (a) Brinker, C. J., Clark, D. E., Ulrich, D. R., Eds. Better Ceramics Through Chemistry II. Mater. Res. Soc. Symp. Proc. 1986, 73. (b) Hubert-Pfalzgraf, L. G. New J. Chem. 1987, 11, 663. (c) Transformation of Organometallics into Common and Exotic Materials; Laine, R. M., Ed.; Martinus Nijhoff: Dordrecht, 1988; pp 207-235 (Ulrich, D. R.) and pp 261-278 (Rinker, C. J.). (d) Hirano, S.; Hayashi, T.; Miura, M.; Tomanaga, H. Bull. Chem. Soc. Jpn. 1989, 62, 888. (e) Goel, S. C.; Kramer, K. S.; Gibbons, P. C.; Buhro, W. E. Inorg. Chem. 1989, 28, 3619. (f) Sanchez, C.; Livage, J. New J. Chem. 1990, 14, 513. (g) Sauer, N. N.; Garcia, E.; Salazar, K. V.; Ryan, R. R.; Martin, J. A. J. Am. Chem. Soc. 1990, 112, 1524 . use of a precursor in which different metal ions are incorporated in the appropriate ratio is known to increase the quality of the resulting (semiconductor) material ${ }^{3}$ and as a consequence heterometallic alkoxides ${ }^{4}$ and a number of preceramic mixedmetal alkoxide aggregates ${ }^{5}$ have been prepared. In addition, lanthanide alkoxides have been found to be active catalysts in a variety of processes. ${ }^{6,7}$ Although lanthanide and group 3 metal alkoxides and aryloxides typically are polymeric, hydrocarbon

(3) Cowley, A. H.; Jones, R. A. Angew. Chem., Int. Ed. Engl. 1989, 28 , 1208.

(4) For a review on heterometallic alkoxides, see: Caulton, K. G.; HubertPfalzgraf, L. G. Chem. Rev. 1990, 90, 969.

(5) (a) Blake, A. J.; Milne, P. E. Y.; Thornton, P.; Winpenny, R. E. P. Angew. Chem., Int. Ed. Engl. 1991, 30, 1139. (b) Wang, S. Inorg. Chem. 1991, 30, 2252. (c) Coan, P. S.; Huffman, J. C.; Caulton, K. G. Inorg. Chem. 1992, 31, 4207. (d) Miele, P.; Foulon, J. D.; Hovnanian, N.; Cot, L. J. Chem. Soc., Chem. Commun. 1993, 29. (e) Bidell, W.; Döring, J.; Bosch, H. W.; Hund, H.-U.; Plappert, E.; Berke, H. Inorg. Chem. 1993, 32, 502. (f) Labrize, F.; Hubert-Pfalzgraf, L. G.; Daran, J.-C.; Halut, S. J. Chem. Soc., Chem. Commun. 1993, 1556 (g) Wang, S.; Pang, Z.; Smith, K. D. L.; Wagner, M. J. J. Chem. Soc., Dalton Trans. 1994, 955.

(6) (a) Namy, J. L.; Souppe, J.; Collin, J.; Kagan, H. B. J. Org. Chem. 1984, 49, 2045. (b) Lebrun, A.; Namy, J. L.; Kagan, H. B. Tetrahedron Lett. 1991, 32, 2355. (c) Sasai, H.; Suzuki, T.; Arai, S.; Arai, T.; Shibasaki, M. J. Am. Chem. Soc. 1992, 114, 4418. (d) Ohno, H.; Mori, A.; Inoue, S. Chem. Lett. 1993, 375. (e) Sasai, H.; Suzuki, T.; Itoh, N.; Shibasaki, M. Tetrahedron Lett. 1993, 34, 851. 
<smiles></smiles><smiles>[R20]NCc1cccc(CN[R2])c1O[M]</smiles><smiles>[Y10]CN([R2])Cc1ccccc1O</smiles><smiles>[R2]NCc1cccc(CNC([R2])[R12])c1O[Y14]</smiles>

[c] [d]<smiles>[Y14]CN([R12])Cc1cccc(CN([R12])[R17])c1O[M]</smiles>

[e]

Figure 1. $o$-Aminophenolate ligands and their coordination possibilities: monodentate $(\mathrm{a}, \mathrm{b}),{ }^{20}$ bidentate $(\mathrm{c}, \mathrm{d}),{ }^{15,16,20}$ and bridging between identical $\left(\mathrm{M}=\mathrm{M}^{\prime}\right)^{17,18}$ or different $\left(\mathrm{M} \neq \mathrm{M}^{\prime}\right)^{19}$ metal centers (e).

insoluble materials, ${ }^{8,9}$ solvent-free complexes are known of sterically demanding ligands (i.e. $\mathrm{OCMeEt}{ }^{\mathrm{i} P r},{ }^{10} \mathrm{OC}_{6} \mathrm{H}_{2}{ }^{\mathrm{t}} \mathrm{Bu}_{2}-2,6-$ $\mathrm{Me}-4^{11}$ ), or of ligands containing potentially intramolecularly coordinating substituents (i.e. $\mathrm{OC}^{t} \mathrm{Bu}_{2} \mathrm{CH}_{2} \mathrm{PMe}_{2},{ }^{12} \mathrm{OC}_{6} \mathrm{H}_{3} \mathrm{Ph}_{2}-$ $\left.2,6^{13}\right) .{ }^{14}$ Recently, we have become interested in group 3 and lanthanide metal complexes with available Lewis acidic sites that might be used to activate aromatic halides toward nucleophilic substitution.

To this end we have applied $o$-amino substituted phenolate ligands of the type $\mathrm{HOC}_{6} \mathrm{H}_{2}\left(\mathrm{CH}_{2} \mathrm{~N}\left(\mathrm{R}^{1}\right) \mathrm{R}^{2}\right)-2-\mathrm{X}-6-\mathrm{R}-4(\mathrm{X}=\mathrm{H}$, $\mathrm{CH}_{2} \mathrm{NR}^{1} \mathrm{R}^{2}$ ) which in their respective phenolate complexes display a variety of coordination geometries ${ }^{15-20}$ (see Figure 1). Moreover, recently we established that neutral phenols can

(7) (a) Schumann, H.; Muller, J.; Genthe, W. Abstract of papers; IX International Conference on Organometallic Chemistry, Dijon, France, 1979; Abstract C60. (b) Schumann, H.; Genthe, W.; Bruncks, N.; Pickardt, J. Organometallics 1982, 1, 1194. (c) Evans, W. J.; Hanusa, T. P.; Levan K. R. Inorg. Chim. Acta 1985, 110, 191. (d) Lappert, M. F.; Smith, R. G. Presented at The Second International Conference on the Basic and Applied Chemistry of f-Transition and Related Elements, Lissabon, 1987; Abstract P(II)1. (e) Hitchcock, P. B.; Lappert, M. F.; Smith, R. G.; Bartlett, R. A.; Power, P. P. J. Chem. Soc., Chem. Commun. 1988, 1007. (f) Heeres, H. J.; Meetsma, A.; Teuben, J. H. J. Chem. Soc., Chem. Commun. 1988, 962.

(8) For a review on lanthanide alkoxide chemistry until 1990 see: Mehrotra, R. C.; Singh, A.; Tripathi, U. M. Chem. Rev. 1991, 91, 1287

(9) Bradley, D. C.; Mehrotra, R. C.; Gaur, D. P. Metal Alkoxides; Academic Press: London, 1978.

(10) Bradley, D. C.; Chudzynska, H.; Hursthouse, M. B.; Motevalli, M. Polyhedron 1991, 10, 1049.

(11) Hitchcock, P. B.; Lappert, M. F.; Singh, A. J. Chem. Soc., Chem. Commun. 1983, 1499.

(12) Hitchcock, P. B.; Lappert, M. F.; MacKinnon, I. A. J. Chem. Soc., Chem. Commun. 1988, 1557.

(13) Deacon, G. B.; Nickel, S.; MacKinnon, P.; Tiekink, E. R. T. Aust. J. Chem. 1990, 43, 1245.

(14) Herrmann, W. A.; Anwander, R.; Denk, M. Chem. Ber. 1992, 125, 2399.

(15) van der Schaaf, P. A.; Jastrzebski, J. T. B. H.; Hogerheide, M. P.; Smeets, W. J. J.; Spek, A. L.; van Koten, G. Inorg. Chem. 1993, 32, 4111.

(16) Alsters, P. L.; Teunissen, H. T.; Boersma, J.; Spek, A. L.; van Koten, G. Organometallics 1993, 12, 4691.

(17) (a) van der Schaaf, P. A.; Jastrzebski, J. T. B. H.; Hogerheide, M. P.; Smeets, W. J. J.; Spek, A. L.; van Koten, G. Inorg. Chem. 1993, 32, 4111. (b) Hogerheide, M. P.; Ringelberg, S. N.; Janssen, M. D.; Boersma, J.; Spek, A. L.; van Koten, G. Inorg. Chem. 1996, 35, 1195. also bind in the zwitterionic form, i.e. as an ammonium phenolate, binding via $\mathrm{O}^{-}$to the metal and forming additional hydrogen bridges through the $-\left(\mathrm{NR}^{1} \mathrm{R}^{2}\right) \mathrm{H}$ group. ${ }^{21}$

In the course of this work we observed some unique examples of cooperative anion-cation bonding, which appeared as the driving force for self-assembly of heteropolymetallic complexes. ${ }^{19}$ This is exemplified by the synthesis and structural features of some hetero(poly)metallic complexes derived from bis(ortho)-chelating $\mathrm{HOC}_{6} \mathrm{H}_{2}\left(\mathrm{CH}_{2} \mathrm{NMe}_{2}\right)_{2}$-2,6-Me-4 and mono(ortho)-chelating $\mathrm{HOC}_{6} \mathrm{H}_{4}\left(\mathrm{CH}_{2} \mathrm{NMe}_{2}\right)-2$. These complexes potentially show the way to a new type of organometallic polymeric materials and might be used as precursors for preceramic mixed-metal complexes.

\section{Experimental Section}

General Data. All reactions were performed using standard Schlenk techniques in an atmosphere of dry, oxygen-free dinitrogen. All solvents were carefully dried and distilled prior to use. Anhydrous $\mathrm{LuCl}_{3}$ and $\mathrm{YCl}_{3}$ were purchased from Strem Chemicals Inc. The phenols $\mathrm{HOC}_{6} \mathrm{H}_{4}\left(\mathrm{CH}_{2} \mathrm{NMe}_{2}\right)-2$ (1) and $\mathrm{HOC}_{6} \mathrm{H}_{2}\left(\mathrm{CH}_{2} \mathrm{NMe}_{2}\right)_{2}$-2,6-Me-4 (2), as well as their sodium salts $\mathrm{NaOC}_{6} \mathrm{H}_{4}\left(\mathrm{CH}_{2} \mathrm{NMe}_{2}\right)-2$ and $\mathrm{NaOC}_{6} \mathrm{H}_{2}\left(\mathrm{CH}_{2} \mathrm{NMe}_{2}\right)_{2}$-2,6-Me-4 were synthesized according to literature procedures. ${ }^{15}$ Elemental analyses were performed by Kolbe Mikroanalytisches Laboratorium, Mülheim, Germany. ${ }^{1} \mathrm{H}$ and ${ }^{13} \mathrm{C}$ NMR data were collected on Bruker AC200 and AC300 instruments. EI-MS spectra $(70 \mathrm{eV})$ were recorded using the direct inlet probe of a Unicam Automass GC-MS spectrometer.

${ }^{89}$ Y NMR Spectroscopy. ${ }^{89} \mathrm{Y}$ NMR spectra were recorded on a Bruker AC200 spectrometer at a transmitter frequency of $9.807 \mathrm{MHz}$, using $10 \mathrm{~mm}$ tubes. Concentrations were $0.6 \mathrm{M} \mathrm{(3b)}$ and $1.5 \mathrm{M} \mathrm{(4)} \mathrm{in}$ $\mathrm{C}_{6} \mathrm{D}_{6}$ and $\mathrm{CDCl}_{3}$, respectively. Because of the long relaxation times of ${ }^{89} \mathrm{Y}$, a delay of $60 \mathrm{~s}$ was used at a pulse width of $20 \mu \mathrm{s}$. A satisfactory signal to noise ratio was typically obtained by accumulation of 40 transients with $16 \mathrm{~K}$ data acquisition points and a spectral width of 3 $\mathrm{kHz}$. To ensure that the observed chemical shifts did not arise from foldovers, the transmitter offset was varied. The chemical shifts are referenced to $3 \mathrm{M} \mathrm{YCl}_{3}$ in $\mathrm{D}_{2} \mathrm{O}(0.0 \mathrm{ppm})$.

$\left\{\mathrm{ClLu}\left[\mathrm{OC}_{6} \mathrm{H}_{2}\left(\mathrm{CH}_{2} \mathrm{NMe}_{2}\right)_{2}-2,6-\mathrm{Me}-4\right]_{3} \mathrm{Na}\right\}$ (3a). To a stirred suspension of $\mathrm{LuCl}_{3}(2.11 \mathrm{~g} ; 7.50 \mathrm{mmol})$ in THF $(50 \mathrm{~mL})$ a solution of $\mathrm{NaOC}_{6} \mathrm{H}_{2}\left(\mathrm{CH}_{2} \mathrm{NMe}_{2}\right)_{2}$-2,6-Me-4 (5.50 g; $\left.22.5 \mathrm{mmol}\right)$ in THF (100 mL) was added dropwise at room temperature. After the mixture was stirred overnight at room temperature, the solvent was removed in vacuo. The resulting residue was extracted twice with hexane $(80 \mathrm{~mL})$. Evaporation of the combined hexane fractions gave the product $\mathbf{3 a}$ as a yellow, crystalline solid $(5.38 \mathrm{~g} ; 80 \%)$. Mp: $180{ }^{\circ} \mathrm{C} \mathrm{dec}$. Yellow crystals suitable for an $\mathrm{X}$-ray structure determination were grown by allowing a concentrated toluene solution to cool to room temperature.

${ }^{1} \mathrm{H}$ NMR data for 3a $\left(\mathrm{C}_{6} \mathrm{D}_{6}, 200 \mathrm{MHz}, 298 \mathrm{~K}\right): \delta 6.81(\mathrm{~s}, 6 \mathrm{H}, \mathrm{Ar})$, $4.42(\mathrm{br}, 3 \mathrm{H}, \mathrm{C} H(\mathrm{H}) \mathrm{N}), 3.79(\mathrm{br}, 3 \mathrm{H}, \mathrm{CH}(\mathrm{H}) \mathrm{N}), 3.29(\mathrm{br}, 3 \mathrm{H}$, $\mathrm{CH}(\mathrm{H}) \mathrm{N}), 2,84(\mathrm{br}, 3 \mathrm{H}, \mathrm{CH}(\mathrm{H}) \mathrm{N}), 2.45$ (s, $\left.18 \mathrm{H}, \mathrm{N}(\mathrm{Me})_{2}\right), 2.26$ (s, 9 $\mathrm{H}, p-M e), 1.74(\mathrm{~s}, 18 \mathrm{H}, \mathrm{NMe}) .{ }^{13} \mathrm{C} \mathrm{NMR}$ data for $3 \mathbf{a}\left(\mathrm{C}_{6} \mathrm{D}_{6}, 50 \mathrm{MHz}\right.$, $298 \mathrm{~K}): \delta 161.72(\mathrm{CO}), 132.64,131.62,125.80,122.50(\mathrm{Ar}), 65.81$ $\left(\mathrm{CH}_{2} \mathrm{~N}\right), 63.01\left(\mathrm{CH}_{2} \mathrm{~N}\right), 47.03\left(\mathrm{NMe}_{2}\right), 46.19(\mathrm{NMe}), 20.65(p-M e)$. Anal. Calcd for $\mathrm{C}_{39} \mathrm{H}_{63} \mathrm{~N}_{6} \mathrm{O}_{3} \mathrm{LuNaCl} \cdot 1.5 \mathrm{C}_{7} \mathrm{H}_{8}: \mathrm{C}, 57.41 ; \mathrm{H}, 7.30 ; \mathrm{N}$, 8.12. Found: C, 56.97; H, 6.79; N, 8.18.

$\left\{\mathrm{CIY}\left[\mathrm{OC}_{6} \mathrm{H}_{2}\left(\mathrm{CH}_{2} \mathrm{NMe}_{2}\right)_{2}-2,6-\mathrm{Me}-4\right]_{3} \mathrm{Na}\right\}(3 \mathrm{~b})$. The preparation of $\mathbf{3 b}$ was identical to that of $\mathbf{3 a}$. Addition of a solution of $\mathrm{NaOC}_{6} \mathrm{H}_{2}\left(\mathrm{CH}_{2}-\right.$ $\left.\mathrm{NMe}_{2}\right)_{2}$-2,6-Me-4 $(5.50 \mathrm{~g} ; 22.5 \mathrm{mmol})$ in THF $(100 \mathrm{~mL})$ to a stirred

(18) (a) van der Schaaf, P. A.; Hogerheide, M. P.; Grove, M. D.; Spek, A. L.; van Koten, G. J. Chem. Soc., Chem. Commun. 1992, 1703. (b) Tesh, K. F.; Hanusa, T. P. J. Chem. Soc., Chem. Commun. 1991, 879. (c) Gultneh, Y.; Farooq, A.; Liu, S.; Karlin, K. D.; Zubieta, J. Inorg. Chem. 1992, 31, 3607. (d) Teipel, S.; Griesar, K.; Haase, W.; Krebs, B. Inorg. Chem. 1994, 33, 456.

(19) Hogerheide, M. P.; Jastrzebski, J. T. B. H.; Boersma, J.; Smeets, W. J. J.; Spek, A. L.; van Koten, G. Inorg. Chem. 1994, 33, 4431.

(20) Hogerheide, M. P.; Wesseling, M.; Jastrzebski, J. T. B. H.; Boersma, J.; Kooijman, H.; Spek, A. L.; van Koten, G. Organometallics 1995, $14,4483$.

(21) Hogerheide, M. P.; Ringelberg, S. N.; Jastrzebski, J. T. B. H.; Boersma, J.; Spek, A. L.; van Koten, G. To be submitted for publication. 
suspension of $\mathrm{YCl}_{3}(1.46 \mathrm{~g} ; 7.50 \mathrm{mmol})$ and subsequent workup afforded $\mathbf{3 b}$ as a yellow, crystalline solid $(4.87 \mathrm{~g} ; 80 \%)$. Mp: $170{ }^{\circ} \mathrm{C}$ dec.

${ }^{1} \mathrm{H}$ NMR data for $3 \mathbf{b}\left(\mathrm{C}_{6} \mathrm{D}_{6}, 200 \mathrm{MHz}, 298 \mathrm{~K}\right): \delta 6.79(\mathrm{~s}, 6 \mathrm{H}, \mathrm{Ar})$, $2.48\left(\mathrm{~s}, 18 \mathrm{H}, \mathrm{N} M e_{2}\right), 2.25$ (s, $\left.9 \mathrm{H}, p-M e\right), 1.70$ (s, $\left.18 \mathrm{H}, \mathrm{N} M e_{2}\right) .{ }^{1} \mathrm{H}$ NMR data for $3 \mathbf{b}\left(\mathrm{C}_{6} \mathrm{D}_{6}, 200 \mathrm{MHz}, 263 \mathrm{~K}\right): \delta 6.77$ (s, $\left.3 \mathrm{H}, \mathrm{Ar}\right), 6.75$ $(\mathrm{s}, 3 \mathrm{H}, \mathrm{Ar}), 5.19\left(\mathrm{~d}, 3 \mathrm{H},{ }^{2} J_{\mathrm{HAHB}}=12 \mathrm{~Hz}, \mathrm{CH}_{\mathrm{A}} \mathrm{H}_{\mathrm{B}} \mathrm{N}\right), 4.21(\mathrm{~d}, 3 \mathrm{H}$, $\left.{ }^{2} J_{\mathrm{HCHD}}=10 \mathrm{~Hz}, \mathrm{CH}_{\mathrm{C}} \mathrm{H}_{\mathrm{D}} \mathrm{N}\right), 2.65\left(\mathrm{~d}, 3 \mathrm{H}, J_{\mathrm{HBHA}}=12 \mathrm{~Hz}, \mathrm{CH}_{\mathrm{A}} H_{\mathrm{B}} \mathrm{N}\right)$, $2.51\left(\mathrm{~s}, 18 \mathrm{H}, \mathrm{NMe} e_{2}\right), 2.27(\mathrm{~s}, 9 \mathrm{H}, p-M e), 2.16\left(\mathrm{~d}, 3 \mathrm{H},{ }^{2} J_{\mathrm{HDHC}}=10\right.$ $\left.\mathrm{Hz}, \mathrm{CH}_{\mathrm{C}} H_{\mathrm{D}} \mathrm{N}\right), 1.55\left(\mathrm{~s}, 18 \mathrm{H}, \mathrm{N} M e_{2}\right) .{ }^{1} \mathrm{H}$ NMR data for $3 \mathbf{b}\left(\mathrm{C}_{6} \mathrm{D}_{6}, 200\right.$ $\mathrm{MHz}, 228 \mathrm{~K}$ ): $\delta 6.77(\mathrm{~s}, 3 \mathrm{H}, \mathrm{Ar}), 6.76(\mathrm{~s}, 3 \mathrm{H}, \mathrm{Ar}), 5.23(\mathrm{~d}, 3 \mathrm{H}$, $\left.{ }^{2} J_{\mathrm{HAHB}}=12 \mathrm{~Hz}, \mathrm{CH}_{\mathrm{A}} \mathrm{H}_{\mathrm{B}} \mathrm{N}\right), 4.25\left(\mathrm{~d}, 3 \mathrm{H},{ }^{2} J_{\mathrm{HCHD}}=11 \mathrm{~Hz}, \mathrm{CH}_{\mathrm{C}} \mathrm{H}_{\mathrm{D}} \mathrm{N}\right)$, $2.63\left(\mathrm{~d}, 3 \mathrm{H}, J_{\mathrm{HBHA}}=12 \mathrm{~Hz}, \mathrm{CH}_{\mathrm{A}} H_{\mathrm{B}} \mathrm{N}\right), 2.53\left(\mathrm{~s}, 18 \mathrm{H}, \mathrm{N} M e_{2}\right), 2.32(\mathrm{~s}$, $9 \mathrm{H}, p-M e), 2.16\left(\mathrm{~d}, 3 \mathrm{H},{ }^{2} J_{\mathrm{HDHC}}=11 \mathrm{~Hz}, \mathrm{CH}_{\mathrm{C}} H_{\mathrm{D}} \mathrm{N}\right), 1.63(\mathrm{~s}, 9 \mathrm{H}$, $\mathrm{NMeMe}), 1.43(\mathrm{~s}, 9 \mathrm{H}, \mathrm{NMe} M e) .{ }^{13} \mathrm{C}$ NMR data for $\mathbf{3 b}\left(\mathrm{C}_{6} \mathrm{D}_{6}, 50\right.$ $\mathrm{MHz}, 298 \mathrm{~K}): \delta 161.79\left(C \mathrm{O},{ }^{2} J_{\mathrm{YC}}=2.2 \mathrm{~Hz}\right), 132.61,131.72,125.70$, 125.40, $122.26(\mathrm{Ar}), 66.23\left(\mathrm{CH}_{2} \mathrm{~N}\right), 63.24\left(\mathrm{CH}_{2} \mathrm{~N}\right), 46.21(\mathrm{NMe}), 20.62$ $(p-M e) .{ }^{13} \mathrm{C}$ NMR data for $3 \mathbf{b}\left(\mathrm{C}_{6} \mathrm{D}_{6}, 50 \mathrm{MHz}, 228 \mathrm{~K}\right): \delta 162.12(\mathrm{CO}$, $\left.{ }^{2} J_{\mathrm{YC}}=2.2 \mathrm{~Hz}\right), 133.01,131.88,125.63,125.54,122.11(\mathrm{Ar}), 66.86$ $\left(\mathrm{CH}_{2} \mathrm{~N}\right), 63.22\left(\mathrm{CH}_{2} \mathrm{~N}\right), 48.37(\mathrm{NMe}), 45.05(\mathrm{NMe}), 44.82(\mathrm{NMe})$, 20.99 (p-Me). MS (EI), $m / z(\%): 776(0.39)\left[\mathrm{M}^{+}-\mathrm{Cl}\right] .{ }^{89} \mathrm{Y}$ NMR data for $\mathbf{3 b}\left(\mathrm{CDCl}_{3}, 9.804 \mathrm{MHz}, 298 \mathrm{~K}\right): \delta 160.9$. Anal. Calcd for $\mathrm{C}_{39} \mathrm{H}_{63} \mathrm{~N}_{6} \mathrm{O}_{3} \mathrm{YNaCl}$ : C, 57.74; $\mathrm{H}, 7.83 ; \mathrm{N}, 10.36$. Found: $\mathrm{C}, 57.79$; $\mathrm{H}, 7.96 ; \mathrm{N}, 10.30$.

$\left[\mathrm{CIY}\left\{\mu-\mathrm{OC}_{6} \mathrm{H}_{4}\left(\mathrm{CH}_{2} \mathrm{NMe}_{2}\right)-2\right\}_{3} \mathrm{Y}\left\{\mathrm{OC}_{6} \mathrm{H}_{4}\left(\mathrm{CH}_{2} \mathrm{NMe}_{2}\right)-2\right\}_{3} \mathrm{Na}\right]$ (4). To a stirred suspension of $\mathrm{YCl}_{3}(1.46 \mathrm{~g} ; 7.50 \mathrm{mmol})$ in THF $(25 \mathrm{~mL})$ a solution of $\mathrm{NaOC}_{6} \mathrm{H}_{4}\left(\mathrm{CH}_{2} \mathrm{NMe}_{2}\right)-2(3.90 \mathrm{~g} ; 22.5 \mathrm{mmol})$ in THF (50 $\mathrm{mL}$ ) was added dropwise at room temperature. After the mixture was stirred overnight, the solvent was removed in vacuo. The residue was extracted twice with $\mathrm{CH}_{2} \mathrm{Cl}_{2}(80 \mathrm{~mL})$. Removal of the solvent in vacuo and subsequent washing of the resulting residue with pentane $(40 \mathrm{~mL})$ gave the product as a white solid in quantitative yield (8.53 g). Mp > $200{ }^{\circ} \mathrm{C}$. Colorless hexagonal crystals of $\mathbf{4}$, suitable for an X-ray analysis, were grown by allowing a hot benzene solution to cool to room temperature.

${ }^{1} \mathrm{H}$ NMR data for $4\left(\mathrm{C}_{6} \mathrm{D}_{6}, 300 \mathrm{MHz}, 298 \mathrm{~K}\right): \delta 7.18(\mathrm{~m}, 1 \mathrm{H}, \mathrm{Ar})$, 7.05 (m, $2 \mathrm{H}, \mathrm{Ar}), 6.87(\mathrm{~m}, 1 \mathrm{H}, \mathrm{Ar}), 6.75(\mathrm{~m}, 1 \mathrm{H}, \mathrm{Ar}), 6.61$ (d, $1 \mathrm{H}$, Ar), $6.51(\mathrm{~d}, 1 \mathrm{H}, \mathrm{Ar}), 5.80(\mathrm{~d}, 1 \mathrm{H}, \mathrm{Ar}), 4.95\left(\mathrm{~d}, 1 \mathrm{H},{ }^{2} J_{\mathrm{HAHB}}=12 \mathrm{~Hz}\right.$, $\left.\mathrm{CH}_{\mathrm{A}} \mathrm{H}_{\mathrm{B}} \mathrm{N}\right), 4.37\left(\mathrm{~d}, 1 \mathrm{H},{ }^{2} J_{\mathrm{HCHD}}=11 \mathrm{~Hz}, \mathrm{CH}_{\mathrm{C}} \mathrm{H}_{\mathrm{D}} \mathrm{N}\right), 2.43(\mathrm{~d}, 1 \mathrm{H}$, $\left.{ }^{2} J_{\mathrm{HBHA}}=12 \mathrm{~Hz}, \mathrm{CH}_{\mathrm{B}} \mathrm{H}_{\mathrm{A}} \mathrm{N}\right), 2.26\left(\mathrm{~d}, 1 \mathrm{H},{ }^{2} J_{\mathrm{HDHC}}=11 \mathrm{~Hz}, \mathrm{CH}_{\mathrm{D}} \mathrm{H}_{\mathrm{C}} \mathrm{N}\right)$, 1.99 (s, $3 \mathrm{H}, \mathrm{NMeMe}), 1.94$ (s, $3 \mathrm{H}, \mathrm{NMeMe}), 1.62$ (s, $\left.6 \mathrm{H}, \mathrm{NMe} e_{2}\right) .{ }^{1} \mathrm{H}$ NMR data for $4\left(\mathrm{CDCl}_{3}, 300 \mathrm{MHz}, 298 \mathrm{~K}\right): \delta 7.18(\mathrm{~d}, 1 \mathrm{H}, \mathrm{Ar}), 7.03$ $(\mathrm{t}, 1 \mathrm{H}, \mathrm{Ar}), 6.88(\mathrm{~m}, 3 \mathrm{H}, \mathrm{Ar}), 6.50(\mathrm{t}, 1 \mathrm{H}, \mathrm{Ar}), 6.29(\mathrm{~d}, 1 \mathrm{H}, \mathrm{Ar})$, $5.32(\mathrm{~d}, 1 \mathrm{H}, \mathrm{Ar}), 4.90\left(\mathrm{~d}, 1 \mathrm{H},{ }^{2} J_{\mathrm{HAHB}}=12 \mathrm{~Hz}, \mathrm{CH}_{\mathrm{A}} \mathrm{H}_{\mathrm{B}} \mathrm{N}\right), 4.03(\mathrm{~d}, 1$ $\left.\mathrm{H},{ }^{2} J_{\mathrm{HCHD}}=11 \mathrm{~Hz}, \mathrm{CH}_{\mathrm{C}} \mathrm{H}_{\mathrm{D}} \mathrm{N}\right), 2.75\left(\mathrm{~d}, 1 \mathrm{H},{ }^{2} J_{\mathrm{HBHA}}=12 \mathrm{~Hz}, \mathrm{CH}_{\mathrm{B}} \mathrm{H}_{\mathrm{A}} \mathrm{N}\right)$, $2.37(\mathrm{~s}, 3 \mathrm{H}, \mathrm{NMeMe}), 2.30(\mathrm{~s}, 3 \mathrm{H}, \mathrm{NMe} M e), 2.12\left(\mathrm{~d}, 1 \mathrm{H},{ }^{2} J_{\mathrm{HDHC}}=\right.$ $\left.11 \mathrm{~Hz}, \mathrm{CH}_{\mathrm{D}} \mathrm{H}_{\mathrm{C}} \mathrm{N}\right), 1.66\left(\mathrm{~s}, 6 \mathrm{H}, \mathrm{NMe} e_{2}\right) .{ }^{13} \mathrm{C} \mathrm{NMR}$ data for $4\left(\mathrm{CDCl}_{3}\right.$, $75 \mathrm{MHz}, 298 \mathrm{~K}): \delta 164.24\left(\mathrm{~d},{ }^{2} J_{\mathrm{YC}}=4.0 \mathrm{~Hz}, C \mathrm{O}\right), 160.01\left(\mathrm{~d},{ }^{2} J_{\mathrm{YC}}=\right.$ $0.6 \mathrm{~Hz}, \mathrm{CO}), 132.22-114.53(\mathrm{Ar}), 64.71\left(\mathrm{CH}_{2} \mathrm{~N}\right), 61.79\left(\mathrm{CH}_{2} \mathrm{~N}\right), 46.57$, 46.37, $45.90\left(\mathrm{NMe}_{2}\right) .{ }^{89} \mathrm{Y}$ NMR data for $4\left(\mathrm{CDCl}_{3}, 9.804 \mathrm{MHz}, 298\right.$ $\mathrm{K}): \delta 202.4\left(\mathrm{~d},{ }^{2} J_{\mathrm{YY}}=0.4 \mathrm{~Hz}\right), 132.4\left(\mathrm{~d},{ }^{2} J_{\mathrm{YY}}=0.4 \mathrm{~Hz}\right)$. Anal. Calcd for $\mathrm{C}_{54} \mathrm{H}_{72} \mathrm{ClN}_{6} \mathrm{NaO}_{6} \mathrm{Y}_{2}$ : C, 57.02; $\mathrm{H}, 6.38 ; \mathrm{N}, 7.32$. Found: C, 57.07; $\mathrm{H}, 6.49$; N, 7.32.

X-ray Data Collection and Structure Refinement. A yellow, block-shaped crystal of 3a and a colorless crystal of $\mathbf{4}$ were each sampled from below the liquid surface directly into a viscous oil to avoid loss of crystallinity (vide infra), glued on top of a glass fiber, and transferred into the cold nitrogen stream on an Enraf-Nonius CAD4T rotating anode diffractometer, using graphite-monochromated $\mathrm{Mo} \mathrm{K} \alpha$ radiation, for data collection. Accurate unit-cell parameters were determined by least-squares treatment of 25 well-centered reflections (SET4) in the range $11.4<\theta<14.7^{\circ}$ and $9.8<\theta<13.6^{\circ}$ for 3a and 4, respectively. All data were collected in $\omega / 2 \theta$ scan mode. Crystal data and details on data collection and refinement are collected in Table 1. Final coordinates for the non-hydrogen atoms are given in Tables 2 and 3, selected bond distances and angles in Tables 4 and 5 for 3a and 4, respectively. Data were corrected for $L p$ effects and for the observed linear decay of the reference reflections. Data for 4 were also corrected for absorption (DIFABS; $;^{22}$ correction range $0.827-$

(22) Walker, N.; Stuart, D. Acta Crystallogr., Sect. A 1983, 39, 158.
Table 1. Crystallographic Data for 3a and 4

\begin{tabular}{|c|c|c|}
\hline & 3a & 4 \\
\hline formula & $\begin{array}{c}\mathrm{C}_{39} \mathrm{H}_{63} \mathrm{~N}_{6} \mathrm{O}_{3} \mathrm{NaLuCl} \cdot \\
\quad 1.5 \mathrm{C}_{7} \mathrm{H}_{8}\end{array}$ & $\begin{array}{c}\mathrm{C}_{54} \mathrm{H}_{66} \mathrm{~N}_{6} \mathrm{O}_{6} \mathrm{NaY}_{2} \mathrm{Cl} \cdot \\
2.69 \mathrm{C}_{6} \mathrm{H}_{6}\end{array}$ \\
\hline fw & $1035.58^{a}$ & $1339.73^{a}$ \\
\hline space group & $P \overline{1}$ (No. 2) & $\bar{P} 1$ (No. 1$)$ \\
\hline$a, \AA$ & $10.706(1)$ & $11.411(4)$ \\
\hline$b, \AA$ & $14.099(2)$ & $13.325(4)$ \\
\hline$c, \AA$ & $18.882(3)$ & $13.599(4)$ \\
\hline$\alpha, \operatorname{deg}$ & $93.48(1)$ & $88.91(3)$ \\
\hline$\beta, \operatorname{deg}$ & $99.49(1)$ & $65.44(2)$ \\
\hline$\gamma$, deg & $108.72(11)$ & $72.77(3)$ \\
\hline$V, \AA^{3}$ & $2642.7(6)$ & $1783.3(11)$ \\
\hline$\rho_{\text {calc }}, \mathrm{g} \mathrm{cm}^{-3}$ & $1.301^{a}$ & $1.248^{a}$ \\
\hline $\mathrm{Z}$ & 2 & 1 \\
\hline$\mu, \mathrm{cm}^{-1}$ & $20.7^{a}$ & $17.2^{a}$ \\
\hline$T, \mathrm{~K}$ & 300 & 150 \\
\hline radiation; $\lambda, \AA$ & Мo K $\alpha ; 0.71073$ & Мо K $\alpha ; 0.71073$ \\
\hline final $R^{b}$ & 0.0411 & $0.062\left[6352 F_{\mathrm{o}}>4 \sigma\left(F_{\mathrm{o}}\right)\right]$ \\
\hline final $w R 2^{c}$ & & 0.1453 \\
\hline final $R_{\mathrm{W}}{ }^{d}$ & 0.0454 & \\
\hline
\end{tabular}

${ }^{a} 2.69$ benzene solvate molecules included. ${ }^{b} R=\sum|| F_{\mathrm{o}}|-| F_{\mathrm{c}}|| /$ $\sum\left|F_{\mathrm{o}}\right| \cdot{ }^{c} \mathrm{wR} 2=\left[\sum\left[w\left(F_{\mathrm{o}}{ }^{2}-F_{\mathrm{c}}{ }^{2}\right)^{2}\right] / \sum\left[w\left(F_{\mathrm{o}}{ }^{2}\right)^{2}\right]\right]^{1 / 2} \cdot{ }^{d} R_{\mathrm{w}}=\left[\Sigma\left[w\left(|| F_{\mathrm{o}} \mid-\right.\right.\right.$ $\left.\left.\left|F_{\mathrm{c}}\right|\right)^{2} / \sum\left[w\left(F_{\mathrm{o}}^{2}\right)\right]\right]^{1 / 2}$.

1.133). The structures were solved by Patterson (3a: DIRDIF) ${ }^{23}$ or direct methods (4: SIR92) ${ }^{24}$ and subsequent difference Fourier techniques. Refinement was carried out by full-matrix least-squares techniques on $F$ (3a: SHELX76) ${ }^{25}$ or on $F^{2}\left(\mathbf{4}\right.$ : SHELXL93). ${ }^{26}$ Hydrogen atoms were introduced on calculated positions and included in the refinement riding on their carrier atoms. All non-hydrogen atoms were refined with anisotropic thermal parameters. The unit cell of $\mathbf{3 a}$ contains a cavity of $745 \AA^{3}$, located around an inversion site, which contains three toluene solvate molecules. Similarly, the unit cell of $\mathbf{4}$ contains a cavity of $561 \AA^{3}$, which contains 2.7 benzene solvate molecules. These toluene and benzene molecules could not be located unambiguously from difference Fourier maps and were taken into account in the structure factor and refinement calculations by Fourier transformation of the diffuse electron density in the cavity (Bypass procedure). ${ }^{27}$ The structure determination for $\mathbf{4}$ showed some disorder in the position of $\mathrm{Y}(1), \mathrm{Na}$ and $\mathrm{Cl}$, which was modeled by inverting the positions of these atoms through the position of $\mathrm{Y}(2)$. The hydrogen atoms of 3a were refined with a common isotropic atomic displacement parameter: $U=0.087(3) \AA^{2}$. The hydrogen atoms of 4 were refined with a fixed isotropic thermal parameter amounting to 1.5 or 1.2 times the value of the equivalent isotropic thermal parameter of their carrier atoms, for the methyl hydrogen atoms and the other hydrogen atoms respectively. Weights were introduced in the last refinement cycles. Neutral atom scattering factors were taken from Cromer and $\mathrm{Mann}^{28}$ and corrected for anomalous dispersion ${ }^{29}$ for 3a. Neutral atom scattering factors and anomalous dispersion corrections were taken from ref 30 for 4. All calculations were carried out on a DECstation 5000 cluster. Geometrical calculations and ORTEP drawings were done with PLATON. ${ }^{31}$ All other drawings were made with PLUTON. ${ }^{32}$

(23) Beurskens, P. T.; Admiraal, G.; Beurskens, G.; Bosman, W. P.; GarcíaGranda, S.; Gould, R. O.; Smits, J. M. M.; Smykalla, C. The DIRDIF program system. Technical Report of the Crystallography Laboratory, University of Nijmegen, The Netherlands, 1992.

(24) Altomare, A.; Cascarano, G.; Giacovazzo, C.; Guagliardi, A. J. Appl. Cryst. 1993, 26, 343.

(25) Sheldrick, G. M. SHELX76. Crystal structure analysis package. University of Cambridge, Cambridge, England, 1976.

(26) Sheldrick, G. M. SHELXL-93. Program for crystal structure refinement. University of Göttingen, Germany, 1993.

(27) van der Sluis, P.; Spek, A. L. Acta Crystallogr., Sect. A 1990, 46, 194.

(28) Cromer, D. T.; Mann, J. B. Acta Crystallogr., Sect. A 1968, 24, 321.

(29) Cromer, D. T.; Liberman, D. J. Chem. Phys. 1970, 53, 1891.

(30) International Tables for Crystallography, Volume C; Wilson, A. J. C., Ed.; Kluwer Academic Publishers: Dordrecht, The Netherlands, 1992.

(31) Spek, A. L. Acta Crystallogr., Sect. A 1990, 46, C34.

(32) Spek, A. L., PLUTON, molecular graphics program. Utrecht University, Utrecht, The Netherlands, 1995. 
Table 2. Final Coordinates and Equivalent Isotropic Thermal Parameters of the Non-Hydrogen Atoms for 3a

\begin{tabular}{|c|c|c|c|c|}
\hline atom & $x$ & $y$ & $z$ & $U_{\text {eq }}\left(\AA^{2}\right)^{a}$ \\
\hline $\mathrm{Lu}$ & $0.76994(2)$ & $0.85892(2)$ & $0.24041(1)$ & $0.0365(1)$ \\
\hline $\mathrm{Cl}$ & $0.51813(13)$ & $0.85386(12)$ & $0.23395(8)$ & $0.0578(5)$ \\
\hline $\mathrm{Na}$ & $1.0793(2)$ & $0.86261(15)$ & $0.24173(11)$ & $0.0506(7)$ \\
\hline $\mathrm{O}(1)$ & $0.8586(3)$ & $0.8263(3)$ & $0.15227(18)$ & $0.0474(12)$ \\
\hline $\mathrm{O}(2)$ & $0.9662(3)$ & $0.9752(2)$ & $0.27397(17)$ & $0.0425(11)$ \\
\hline $\mathrm{O}(3)$ & $0.8774(3)$ & $0.7736(2)$ & $0.29896(17)$ & $0.0427(11)$ \\
\hline $\mathrm{N}(1)$ & $0.6170(4)$ & $0.6753(3)$ & $0.1789(2)$ & $0.0521(16)$ \\
\hline $\mathrm{N}(2)$ & $1.1517(5)$ & $0.9084(4)$ & $0.1110(3)$ & $0.0657(19)$ \\
\hline $\mathrm{N}(3)$ & $1.2756(4)$ & $1.0052(3)$ & $0.3409(2)$ & $0.0520(16)$ \\
\hline $\mathrm{N}(4)$ & $0.7499(4)$ & $1.0131(3)$ & $0.1708(2)$ & $0.0506(17)$ \\
\hline $\mathrm{N}(5)$ & $0.7507(4)$ & $0.8950(3)$ & $0.3744(2)$ & $0.0425(14)$ \\
\hline $\mathrm{N}(6)$ & $1.1144(5)$ & $0.6855(3)$ & $0.2763(3)$ & $0.0559(17)$ \\
\hline $\mathrm{C}(1)$ & $0.8560(5)$ & $0.7559(4)$ & $0.1011(3)$ & $0.0473(17)$ \\
\hline$C(2)$ & $0.7750(5)$ & $0.6554(4)$ & $0.0984(3)$ & $0.0525(17)$ \\
\hline $\mathrm{C}(3)$ & $0.7737(6)$ & $0.5856(5)$ & $0.0427(3)$ & $0.075(2)$ \\
\hline C(4) & $0.8504(7)$ & $0.6113(6)$ & $-0.0101(4)$ & $0.089(3)$ \\
\hline$C(5)$ & $0.9304(6)$ & $0.7099(5)$ & $-0.0054(3)$ & $0.074(3)$ \\
\hline$C(6)$ & $0.9366(5)$ & $0.7836(4)$ & $0.0489(3)$ & $0.0500(19)$ \\
\hline$C(7)$ & $0.7019(6)$ & $0.6189(4)$ & $0.1584(3)$ & $0.0564(17)$ \\
\hline $\mathrm{C}(8)$ & $0.5165(6)$ & $0.6727(6)$ & $0.1137(3)$ & $0.078(2)$ \\
\hline $\mathrm{C}(9)$ & $0.5462(7)$ & $0.6211(5)$ & $0.2324(4)$ & $0.075(3)$ \\
\hline$C(10)$ & $0.8468(9)$ & $0.5319(7)$ & $-0.0694(5)$ & $0.137(4)$ \\
\hline $\mathrm{C}(11)$ & $1.0306(6)$ & $0.8880(4)$ & $0.0542(3)$ & $0.0548(19)$ \\
\hline$C(12)$ & $1.2268(8)$ & $1.0186(6)$ & $0.1195(4)$ & $0.106(3)$ \\
\hline$C(13)$ & $1.2353(6)$ & $0.8537(6)$ & $0.0896(4)$ & $0.087(3)$ \\
\hline$C(14)$ & $1.0313(5)$ & $1.0732(4)$ & $0.2750(3)$ & $0.0443(17)$ \\
\hline$C(15)$ & $1.1490(5)$ & $1.1246(4)$ & $0.3274(3)$ & $0.0491(17)$ \\
\hline$C(16)$ & $1.2064(6)$ & $1.2269(4)$ & $0.3291(4)$ & $0.065(2)$ \\
\hline$C(17)$ & $1.1592(7)$ & $1.2836(5)$ & $0.2827(4)$ & $0.075(3)$ \\
\hline $\mathrm{C}(18)$ & $1.0515(7)$ & $1.2309(5)$ & $0.2274(4)$ & $0.072(3)$ \\
\hline$C(19)$ & $0.9881(5)$ & $1.1276(4)$ & $0.2224(3)$ & $0.0499(17)$ \\
\hline$C(20)$ & $1.2114(5)$ & $1.0667(4)$ & $0.3767(3)$ & $0.0495(17)$ \\
\hline$C(21)$ & $1.3899(6)$ & $1.0694(5)$ & $0.3152(4)$ & $0.074(3)$ \\
\hline $\mathrm{C}(22)$ & $1.3232(7)$ & $0.9459(5)$ & $0.3931(4)$ & $0.079(3)$ \\
\hline $\mathrm{C}(23)$ & $1.2214(9)$ & $1.3969(5)$ & $0.2877(5)$ & $0.118(4)$ \\
\hline$C(24)$ & $0.8829(6)$ & $1.0716(4)$ & $0.1568(3)$ & $0.058(2)$ \\
\hline$C(25)$ & $0.6627(6)$ & $0.9658(5)$ & $0.0998(3)$ & $0.073(3)$ \\
\hline$C(26)$ & $0.6927(6)$ & $1.0830(5)$ & $0.2034(4)$ & $0.072(3)$ \\
\hline $\mathrm{C}(27)$ & $0.9249(4)$ & $0.7569(3)$ & $0.3645(3)$ & $0.0380(16)$ \\
\hline $\mathrm{C}(28)$ & $0.9207(5)$ & $0.8144(4)$ & $0.4267(3)$ & $0.0436(17)$ \\
\hline $\mathrm{C}(29)$ & $0.9655(6)$ & $0.7934(5)$ & $0.4954(3)$ & $0.060(2)$ \\
\hline$C(30)$ & $1.0190(7)$ & $0.7161(6)$ & $0.5043(3)$ & $0.074(3)$ \\
\hline $\mathrm{C}(31)$ & $1.0271(6)$ & $0.6606(5)$ & $0.4424(3)$ & $0.063(2)$ \\
\hline $\mathrm{C}(32)$ & $0.9839(5)$ & $0.6807(4)$ & $0.3730(3)$ & $0.0474(17)$ \\
\hline C(33) & $0.8810(5)$ & $0.9074(4)$ & $0.4221(3)$ & $0.0453(17)$ \\
\hline C(34) & $0.7304(6)$ & $0.9935(5)$ & $0.3831(3)$ & $0.063(2)$ \\
\hline$C(35)$ & $0.6439(5)$ & $0.8175(5)$ & $0.3984(3)$ & $0.0587(19)$ \\
\hline$C(36)$ & $1.0673(10)$ & $0.6915(8)$ & $0.5797(4)$ & $0.123(5)$ \\
\hline $\mathrm{C}(37)$ & $1.0016(5)$ & $0.6255(4)$ & $0.3077(3)$ & $0.0541(19)$ \\
\hline C(38) & $1.1093(8)$ & $0.6378(5)$ & $0.2052(3)$ & $0.083(3)$ \\
\hline $\mathrm{C}(39)$ & $1.2416(6)$ & $0.6936(5)$ & $0.3223(4)$ & $0.068(2)$ \\
\hline
\end{tabular}

${ }^{a} U(\mathrm{eq})=$ one-third of the trace of the orthogonalized $\mathbf{U}$.

\section{Results}

Syntheses and Properties. Reaction of lutetium or yttrium trichloride with 3 equiv of $\mathrm{NaOC}_{6} \mathrm{H}_{2}\left(\mathrm{CH}_{2} \mathrm{NMe}_{2}\right)_{2}-2$, $6-\mathrm{Me}-4$ or $\mathrm{NaOC}_{6} \mathrm{H}_{4}\left(\mathrm{CH}_{2} \mathrm{NMe}_{2}\right)-2$ at room temperature in THF, resulted in the formation of heterometallic complexes $\mathrm{Na}\left[\mathrm{M}(\mathrm{OAr})_{3}\right]_{x} \mathrm{Cl}$ $\left(x=1, \mathrm{OAr}=\mathrm{OC}_{6} \mathrm{H}_{2}\left(\mathrm{CH}_{2} \mathrm{NMe}_{2}\right)_{2}-2,6-\mathrm{Me}-4, \mathrm{M}=\mathrm{Lu}(3 \mathbf{a}), \mathrm{Y}\right.$ (3b); $\left.x=2, \mathrm{OAr}=\mathrm{OC}_{6} \mathrm{H}_{4}\left(\mathrm{CH}_{2} \mathrm{NMe}_{2}\right)-2, \mathrm{M}=\mathrm{Y}(\mathbf{4})\right)$. These complexes were obtained as crystalline solids in $80 \%$ (3a and 3b) or essentially quantitative (4) yield (see Schemes 1 and 2).

Complexes $\mathbf{3}$ and $\mathbf{4}$ are easily hydrolyzed with formation of the corresponding parent phenols, $\mathbf{2}$ and $\mathbf{1}$, respectively. All complexes are soluble in THF and aromatic solvents, while $\mathbf{3 a}$ and $\mathbf{3 b}$ are also soluble in hexane. The complexes can be (re)crystallized by allowing a hot, concentrated solution in an aromatic solvent to cool to room temperature, with the formation (for all three complexes) of colorless, hexagonal crystals. However, these crystals contain a relatively large percentage of the crystallization solvent (28 and $31 \mathrm{wt} \%$ for 3a and 4, respectively) and lose their crystallinity upon removal of the supernatant liquid, leaving the crystals fragile and nontransparent.

Structures in the Solid State. In order to gain insight into the coordination geometries for the metal centers in both the complexes $\mathbf{3}$ and $\mathbf{4}$, as well as the incorporation of one $\mathrm{NaCl}$ molecule in both these complexes, the solid state structures of $\mathbf{3 a}$ and $\mathbf{4}$ were determined.

Complex $\left\{\mathrm{ClLu}\left[\mathrm{OC}_{6} \mathrm{H}_{2}\left(\mathrm{CH}_{2} \mathrm{NMe}_{2}\right)_{2}-2,6-\mathrm{Me}-4\right]_{3} \mathrm{Na}\right\}$, 3a. The molecular structure (see Figure 2 and Scheme 1) shows $\mathbf{3 a}$ to consist of a seven-coordinate lutetium ion surrounded by three phenolate ligands, each bonded through oxygen and coordinating with one of the ortho amino substituents, and one chloride atom. This anionic "ate"-unit still has six available binding sites comprising the remaining three ortho amino substituents and the three phenolate oxygen atoms. These binding sites are arranged in such a way that they form a hexadentate coordination pocket for binding of the sodium cation. The chloride, lutetium, and sodium atoms lie on a pseudo-3-fold axis $(\angle \mathrm{Cl}-$ $\left.\mathrm{Lu} \cdots \mathrm{Na}=177.82(5)^{\circ}\right)$, around which the three ligands are arranged (see Figure 3). As a result of the intramolecular coordination of the amino substituents of each bis(amino)phenolate ligand to two different metal centers ( $\mathrm{Lu}$ and $\mathrm{Na}$ ), the aromatic ring-plane of each ligand is twisted away from a position perpendicular to the $\mathrm{Cl}-\mathrm{Lu} \cdots \mathrm{Na}$ vector, resulting in a "propeller-like" molecule with screw-type chirality. Both enantiomers were present in the measured crystal.

As may be expected, the $\mathrm{Lu}-\mathrm{O}$ bond lengths of 2.143(3) to 2.174(3) $\AA$ of the bridging phenolate ligands in 3a are much larger than those of terminal phenolate ligands (e.g. in Lu$\left.\left[\mathrm{OC}_{6} \mathrm{H}_{3}\left({ }^{\mathrm{i}} \mathrm{Pr}\right)_{2}-2,6\right]_{3}(\mathrm{THF})_{2}(\mathbf{5}): 2.041(4)-2.048(4) \AA\right) .{ }^{33}$ The $\mathrm{Lu}-\mathrm{O}-\mathrm{C}$ bond angles in 3a lie in the range 143.0(3) to $145.5(4)^{\circ}$, as a result of their bridging character and the intramolecular coordination of one of the amino substituents to lutetium. Reduction of the $\mathrm{M}-\mathrm{O}-\mathrm{C}$ angle as a result of intramolecular coordination has been observed previously for $\mathrm{Yb}\left(\mathrm{OC}_{6} \mathrm{H}_{3} \mathrm{Ph}_{2}-2,6\right)_{3}$, in which the $\mathrm{Yb}-\pi$-arene interaction of the ytterbium ion with a phenyl substituent of one of the terminal phenolate ligands leads to an even smaller angle of $135.0(3)^{\circ} .{ }^{13}$

The bond angles around the sodium ion show that it is bonded more strongly to one of the phenolate ligands than to the other two. The $\mathrm{Na}-\mathrm{O}(2)$ bond length of 2.391(4) $\AA$ is much shorter than the other $\mathrm{Na}-\mathrm{O}$ bond lengths (2.550(4) $\AA$ and 2.571(4) $\AA$ ), but is comparable to the $\mathrm{Na}-\mathrm{O}$ bond lengths in $\left[\mathrm{NaOC}_{6} \mathrm{H}_{2}\left(\mathrm{CH}_{2} \mathrm{NMe}_{2}\right)_{2}-2,6-\mathrm{Me}-4\right]_{4} \quad(\mathbf{6}) .{ }^{15}$ In addition, the $\mathrm{Na}-\mathrm{O}(2)-\mathrm{C}(14)$ bond angle of $116.6(3)^{\circ}$ differs substantially from the corresponding bond angles found for the other two ligands (105.9(3) and 107.7(3) $)^{\circ}$. The $\mathrm{Na}-\mathrm{N}$ bond lengths in 3a fall in a narrow range $(2.738(5)-2.759(6) \AA)$, but are much longer than those found in $6(2.468(3)-2.664(5) \AA)$. So, in the solid state, the sodium ion can be seen as four-coordinate $\left(\mathrm{ON}_{3}\right)$ with two additional, slightly remote $\mathrm{Na}-\mathrm{O}$ interactions.

An interesting feature concerns the crystal packing of the complex. In this packing the lutetium-chloride vector of one residue points to the sodium ion captured in the pocket of the next residue, thus forming a continuous $\{(\mathrm{Na} \cdots \mathrm{Lu}-\mathrm{Cl}) \cdots(\mathrm{Na} \cdots$ $\mathrm{Lu}-\mathrm{Cl})\}_{n}$ string through the crystal. However, the intermolecular distance between the chloride of one unit and the sodium of the next is at $4.765(3) \AA$ nearly double the sum of the covalent radii $(2.53 \AA)$.

Complex [CIY $\left\{\mu-\mathrm{OC}_{6} \mathrm{H}_{4}\left(\mathrm{CH}_{2} \mathrm{NMe}_{2}\right)-2\right\}_{3} \mathrm{Y}\left\{\mathrm{OC}_{6} \mathrm{H}_{4}\left(\mathrm{CH}_{2} \mathrm{~N}-\right.\right.$ $\left.\left.\mathrm{Me}_{2}\right)-2\right\}_{3} \mathrm{Na}$ ], 4. Complex 4 consists of one chlorine atom, two

(33) Barnhart, D. M.; Clark, D. L.; Gordon, J. C.; Huffman, J. C.; Vincent, R. L.; Watkin, J. G.; Zwick, B. D. Inorg. Chem. 1994, 33, 3487. 
Table 3. Final Coordinates and Equivalent Isotropic Thermal Parameters of the Non-Hydrogen Atoms for 4

\begin{tabular}{|c|c|c|c|c|c|c|c|c|c|}
\hline atom & $x$ & $y$ & $z$ & $U_{\mathrm{eq}}\left(\AA^{2}\right)^{a}$ & atom & $x$ & $y$ & $z$ & $U_{\text {eq }}\left(\AA^{2}\right)^{a}$ \\
\hline $\mathrm{Y}(1)^{b}$ & $0.03797(13)$ & $0.59901(9)$ & $0.19023(11)$ & $0.0320(4)$ & $\mathrm{C}(32)$ & $0.3965(9)$ & $0.6142(6)$ & $0.1254(8)$ & $0.040(3)$ \\
\hline$Y(2)$ & 0.03070 & 0.85730 & 0.19390 & $0.0346(3)$ & $C(33)$ & $0.5372(10)$ & $0.5807(7)$ & $0.0805(10)$ & $0.060(4)$ \\
\hline $\mathrm{Cl}^{\mathrm{b}}$ & $0.0422(3)$ & $0.4026(2)$ & $0.1898(2)$ & $0.0407(10)$ & $\mathrm{C}(34)$ & $0.6099(10)$ & $0.6008(8)$ & $-0.0188(10)$ & $0.069(4)$ \\
\hline $\mathrm{Na}^{\mathrm{b}}$ & $0.0304(4)$ & $1.0939(3)$ & $0.1997(4)$ & $0.0238(12)$ & $C(35)$ & $0.5434(11)$ & $0.6604(8)$ & $-0.0737(9)$ & $0.069(4)$ \\
\hline $\mathrm{O}(1)$ & $-0.0741(5)$ & $0.7499(4)$ & $0.1469(5)$ & $0.0471(19)$ & $C(36)$ & $0.3999(14)$ & $0.6941(9)$ & $-0.0314(11)$ & $0.082(5)$ \\
\hline $\mathrm{O}(2)$ & $-0.0004(6)$ & $0.7266(4)$ & $0.3168(5)$ & $0.0447(19)$ & $C(37)$ & $0.3117(9)$ & $0.5912(7)$ & $0.2416(7)$ & $0.040(3)$ \\
\hline $\mathrm{O}(3)$ & $0.1881(6)$ & $0.6844(4)$ & $0.1073(5)$ & $0.048(2)$ & $\mathrm{C}(38)$ & $0.1640(10)$ & $0.4933(8)$ & $0.3603(8)$ & $0.062(4)$ \\
\hline $\mathrm{O}(4)$ & $-0.1455(7)$ & $0.9868(4)$ & $0.2801(5)$ & $0.057(2)$ & C(39) & $0.3314(11)$ & $0.4145(8)$ & $0.1814(10)$ & $0.075(5)$ \\
\hline $\mathrm{O}(5)$ & $0.1445(6)$ & $0.9179(4)$ & $0.2501(5)$ & $0.056(2)$ & $\mathrm{C}(41)$ & $-0.2757(10)$ & $1.0444(6)$ & $0.3344(9)$ & $0.050(4)$ \\
\hline $\mathrm{O}(6)$ & $0.0872(6)$ & $0.9353(5)$ & $0.0542(5)$ & $0.052(2)$ & $\mathrm{C}(42)$ & $-0.3289(11)$ & $1.1175(7)$ & $0.2741(9)$ & $0.055(4)$ \\
\hline $\mathrm{N}(1)$ & $0.0780(7)$ & $0.5606(5)$ & $-0.0072(5)$ & $0.038(2)$ & C (43) & $-0.4702(11)$ & $1.1672(7)$ & $0.3229(10)$ & $0.066(4)$ \\
\hline $\mathrm{N}(2)$ & $-0.1982(6)$ & $0.6230(5)$ & $0.3370(5)$ & $0.040(2)$ & C(44) & $-0.5518(13)$ & $1.1580(9)$ & $0.4264(13)$ & $0.103(6)$ \\
\hline $\mathrm{N}(3)$ & $0.2372(7)$ & $0.5162(5)$ & $0.2406(6)$ & $0.042(3)$ & $\mathrm{C}(45)$ & $-0.4827(11)$ & $1.0852(8)$ & $0.4819(9)$ & $0.069(4)$ \\
\hline $\mathrm{N}(4)$ & $-0.1594(9)$ & $1.2034(6)$ & $0.1517(8)$ & $0.057(3)$ & $C(46)$ & $-0.3493(10)$ & $1.0327(7)$ & $0.4341(9)$ & $0.051(3)$ \\
\hline $\mathrm{N}(5)$ & $0.0019(8)$ & $1.1545(6)$ & $0.3909(6)$ & $0.050(3)$ & C(47) & $-0.2442(11)$ & $1.1342(7)$ & $0.1586(9)$ & $0.060(4)$ \\
\hline $\mathrm{N}(6)$ & $0.2656(8)$ & $1.0937(6)$ & $0.0453(7)$ & $0.056(3)$ & $\mathrm{C}(48)$ & $-0.0874(13)$ & $1.2076(10)$ & $0.0457(11)$ & $0.090(6)$ \\
\hline $\mathrm{C}(11)$ & $-0.1336(9)$ & $0.7814(7)$ & $0.0776(7)$ & $0.040(3)$ & C(49) & $-0.2512(10)$ & $1.3036(7)$ & $0.2129(9)$ & $0.063(4)$ \\
\hline $\mathrm{C}(12)$ & $-0.0646(9)$ & $0.7324(6)$ & $-0.0276(7)$ & $0.039(3)$ & $\mathrm{C}(51)$ & $0.2170(9)$ & $0.9177(6)$ & $0.3063(8)$ & $0.045(3)$ \\
\hline $\mathrm{C}(13)$ & $-0.1274(10)$ & $0.7597(7)$ & $-0.0985(7)$ & $0.054(3)$ & $\mathrm{C}(52)$ & $0.1624(9)$ & $0.9840(6)$ & $0.4037(7)$ & $0.034(3)$ \\
\hline$C(14)$ & $-0.2565(10)$ & $0.8364(8)$ & $-0.0609(8)$ & $0.055(4)$ & $\mathrm{C}(53)$ & $0.2359(10)$ & $0.9760(6)$ & $0.4606(7)$ & $0.051(3)$ \\
\hline$C(15)$ & $-0.3231(9)$ & $0.8863(7)$ & $0.0430(8)$ & $0.051(3)$ & $\mathrm{C}(54)$ & $0.3655(10)$ & $0.9047(8)$ & $0.4223(8)$ & $0.059(4)$ \\
\hline $\mathrm{C}(16)$ & $-0.2572(11)$ & $0.8603(7)$ & $0.1065(9)$ & $0.049(4)$ & $\mathrm{C}(55)$ & $0.4223(11)$ & $0.8486(7)$ & $0.3239(11)$ & $0.075(5)$ \\
\hline $\mathrm{C}(17)$ & $0.0710(9)$ & $0.6560(7)$ & $-0.0676(7)$ & $0.045(3)$ & $C(56)$ & $0.3463(9)$ & $0.8558(7)$ & $0.2633(7)$ & $0.042(3)$ \\
\hline $\mathrm{C}(18)$ & $0.2154(10)$ & $0.4892(8)$ & $-0.0577(8)$ & $0.060(4)$ & $\mathrm{C}(57)$ & $0.0169(9)$ & $1.0599(6)$ & $0.4449(7)$ & $0.043(3)$ \\
\hline C(19) & $-0.0070(11)$ & $0.5067(7)$ & $-0.0257(8)$ & $0.067(4)$ & $\mathrm{C}(58)$ & $-0.1411(11)$ & $1.2212(7)$ & $0.4386(9)$ & $0.066(4)$ \\
\hline $\mathrm{C}(21)$ & $-0.0795(10)$ & $0.7595(7)$ & $0.4274(9)$ & $0.049(4)$ & $\mathrm{C}(59)$ & $0.0888(10)$ & $1.2160(7)$ & $0.3968(8)$ & $0.053(4)$ \\
\hline$C(22)$ & $-0.2146(10)$ & $0.7561(7)$ & $0.4734(8)$ & $0.048(3)$ & $\mathrm{C}(61)$ & $0.1594(12)$ & $0.9426(8)$ & $-0.0520(8)$ & $0.058(4)$ \\
\hline$C(23)$ & $-0.2929(11)$ & $0.7785(8)$ & $0.5748(9)$ & $0.067(4)$ & $\mathrm{C}(62)$ & $0.2862(11)$ & $0.9635(8)$ & $-0.0880(9)$ & $0.057(4)$ \\
\hline $\mathrm{C}(24)$ & $-0.2464(14)$ & $0.8026(9)$ & $0.6441(10)$ & $0.095(5)$ & $\mathrm{C}(63)$ & $0.3552(11)$ & $0.9585(7)$ & $-0.2033(8)$ & $0.059(4)$ \\
\hline $\mathrm{C}(25)$ & $-0.1134(13)$ & $0.8143(7)$ & $0.6089(9)$ & $0.076(5)$ & C(64) & $0.3040(14)$ & $0.9429(10)$ & $-0.2717(10)$ & $0.096(6)$ \\
\hline $\mathrm{C}(26)$ & $-0.0336(11)$ & $0.7900(7)$ & $0.4943(7)$ & $0.041(3)$ & $\mathrm{C}(65)$ & $0.1772(14)$ & $0.9269(9)$ & $-0.2317(9)$ & $0.092(6)$ \\
\hline$C(27)$ & $-0.2770(11)$ & $0.7320(8)$ & $0.3951(8)$ & $0.058(4)$ & $\mathrm{C}(66)$ & $0.1139(12)$ & $0.9246(9)$ & $-0.1252(11)$ & $0.081(5)$ \\
\hline $\mathrm{C}(28)$ & $-0.2693(10)$ & $0.5975(7)$ & $0.2689(8)$ & $0.053(4)$ & $\mathrm{C}(67)$ & $0.3373(8)$ & $0.9883(6)$ & $-0.0167(7)$ & $0.040(3)$ \\
\hline$C(29)$ & $-0.2089(11)$ & $0.5489(7)$ & $0.4152(8)$ & $0.059(4)$ & $\mathrm{C}(68)$ & $0.3292(12)$ & $1.1068(9)$ & $0.1130(10)$ & $0.079(5)$ \\
\hline $\mathrm{C}(31)$ & $0.3284(9)$ & $0.6601(7)$ & $0.0694(8)$ & $0.048(3)$ & C(69) & $0.2768(10)$ & $1.1748(6)$ & $-0.0268(7)$ & $0.051(3)$ \\
\hline
\end{tabular}

${ }^{a} U(\mathrm{eq})=$ one-third of the trace of the orthogonalized $\mathbf{U} .{ }^{b}$ Disordered atoms (see Experimental Section).

Table 4. Selected Bond Distances and Angles for Complex 3a

\begin{tabular}{llll} 
& \multicolumn{3}{c}{ Bond Lengths $(\AA)$} \\
$\mathrm{Lu}-\mathrm{Cl}$ & $2.6561(15)$ & $\mathrm{Na}-\mathrm{O}(1)$ & $2.550(4)$ \\
$\mathrm{Lu}-\mathrm{O}(1)$ & $2.143(3)$ & $\mathrm{Na}-\mathrm{O}(2)$ & $2.391(4)$ \\
$\mathrm{Lu}-\mathrm{O}(2)$ & $2.174(3)$ & $\mathrm{Na}-\mathrm{O}(3)$ & $2.571(4)$ \\
$\mathrm{Lu}-\mathrm{O}(3)$ & $2.150(3)$ & $\mathrm{Na}-\mathrm{N}(2)$ & $2.759(6)$ \\
$\mathrm{Lu}-\mathrm{N}(1)$ & $2.649(4)$ & $\mathrm{Na}-\mathrm{N}(3)$ & $2.738(4)$ \\
$\mathrm{Lu}-\mathrm{N}(4)$ & $2.656(4)$ & $\mathrm{Na}-\mathrm{N}(6)$ & $2.743(5)$ \\
$\mathrm{Lu}-\mathrm{N}(5)$ & $2.605(4)$ & $\mathrm{Lu}-\mathrm{Na}$ & $3.292(2)$ \\
$\mathrm{C}(1)-\mathrm{O}(1)$ & $1.333(7)$ & $\mathrm{C}(27)-\mathrm{O}(3)$ & $1.323(6)$ \\
$\mathrm{C}(14)-\mathrm{O}(2)$ & $1.330(6)$ & & \\
\multicolumn{5}{c}{} \\
$\mathrm{Lu}-\mathrm{O}(1)-\mathrm{C}(1)$ & $145.5(4)$ & $\mathrm{Na}-\mathrm{O}(1)-\mathrm{C}(1)$ & $105.9(3)$ \\
$\mathrm{Lu}-\mathrm{O}(2)-\mathrm{C}(14)$ & $143.0(3)$ & $\mathrm{Na}-\mathrm{O}(2)-\mathrm{C}(14)$ & $116.6(3)$ \\
$\mathrm{Lu}-\mathrm{O}(3)-\mathrm{C}(27)$ & $143.9(3)$ & $\mathrm{Na}-\mathrm{O}(3)-\mathrm{C}(27)$ & $107.7(3)$ \\
$\mathrm{Na} \cdots \mathrm{Lu}-\mathrm{Cl}$ & $177.82(5)$ &
\end{tabular}

yttrium atoms, and one sodium atom lying on a pseudo-3-fold axis $\left(\angle \mathrm{Cl}-\mathrm{Y}(1)-\mathrm{Y}(2)=179.36(8)^{\circ} ; \angle \mathrm{Y}(1)-\mathrm{Y}(2) \cdots \mathrm{Na}=\right.$ $\left.178.38(10)^{\circ}\right)$, around which six mono(amino)phenolate ligands are arranged in two separate shells (see Figure 4 and Scheme 2). Three of the phenolate ligands ("first shell") are associated to both yttrium atoms, each bridging $\mathrm{Y}(1)$ and $\mathrm{Y}(2)$ with their oxygen atoms and coordinating with their $o$-amino substituent to $\mathrm{Y}(1)$. The distance between the two yttrium atoms is at 3.4189(17) $\AA$ only slightly larger than the sum of the covalent radii $(3.24 \AA) .{ }^{30}$ The coordination sphere of $\mathrm{Y}(1)$ is completed by a chloride atom, making it seven coordinate with a coordination geometry that is fully analogous to that around $\mathrm{Lu}$ in $\mathbf{3 a}$. The second group of three phenolate ligands ("second shell") is bonded through oxygen to $\mathrm{Y}(2)$, thus creating a six-coordinate geometry around this Y-center. The three amino substituents of these phenolate ligands form, together with their oxygen
Table 5. Selected Bond Distances and Angles for Complex 4

\begin{tabular}{llll}
\hline \multicolumn{4}{c}{ Bond Lengths $(\AA)$} \\
$\mathrm{Y}(1)-\mathrm{Cl}$ & $2.603(3)$ & $\mathrm{Y}(2)-\mathrm{O}(1)$ & $2.360(6)$ \\
$\mathrm{Y}(1)-\mathrm{O}(1)$ & $2.255(6)$ & $\mathrm{Y}(2)-\mathrm{O}(2)$ & $2.391(6)$ \\
$\mathrm{Y}(1)-\mathrm{O}(2)$ & $2.256(6)$ & $\mathrm{Y}(2)-\mathrm{O}(3)$ & $2.411(6)$ \\
$\mathrm{Y}(1)-\mathrm{O}(3)$ & $2.236(7)$ & $\mathrm{Y}(2)-\mathrm{O}(4)$ & $2.111(6)$ \\
$\mathrm{Y}(1)-\mathrm{N}(1)$ & $2.564(7)$ & $\mathrm{Y}(2)-\mathrm{O}(5)$ & $2.096(7)$ \\
$\mathrm{Y}(1)-\mathrm{N}(2)$ & $2.528(7)$ & $\mathrm{Y}(2)-\mathrm{O}(6)$ & $2.100(6)$ \\
$\mathrm{Y}(1)-\mathrm{N}(3)$ & $2.576(9)$ & $\mathrm{Y}(2)-\mathrm{Na}$ & $3.154(4)$ \\
$\mathrm{Y}(1)-\mathrm{Y}(2)$ & $3.4189(17)$ & & \\
$\mathrm{Na}-\mathrm{O}(4)$ & $2.660(9)$ & $\mathrm{O}(1)-\mathrm{C}(11)$ & $1.369(12)$ \\
$\mathrm{Na}-\mathrm{O}(5)$ & $2.557(7)$ & $\mathrm{O}(2)-\mathrm{C}(21)$ & $1.390(13)$ \\
$\mathrm{Na}-\mathrm{O}(6)$ & $2.661(8)$ & $\mathrm{O}(3)-\mathrm{C}(31)$ & $1.395(14)$ \\
$\mathrm{Na}-\mathrm{N}(4)$ & $2.552(11)$ & $\mathrm{O}(4)-\mathrm{C}(41)$ & $1.333(13)$ \\
$\mathrm{Na}-\mathrm{N}(5)$ & $2.596(9)$ & $\mathrm{O}(5)-\mathrm{C}(51)$ & $1.339(13)$ \\
$\mathrm{Na}-\mathrm{N}(6)$ & $2.631(11)$ & $\mathrm{O}(6)-\mathrm{C}(61)$ & $1.352(12)$
\end{tabular}

$\begin{array}{llll} & \text { Bond Angles (deg) } & \\ \mathrm{Y}(1)-\mathrm{O}(1)-\mathrm{C}(11) & 139.0(5) & \mathrm{Y}(2)-\mathrm{O}(4)-\mathrm{C}(41) & 161.1(6) \\ \mathrm{Y}(1)-\mathrm{O}(2)-\mathrm{C}(21) & 138.9(6) & \mathrm{Y}(2)-\mathrm{O}(5)-\mathrm{C}(51) & 154.9(5) \\ \mathrm{Y}(1)-\mathrm{O}(3)-\mathrm{C}(31) & 135.1(5) & \mathrm{Y}(2)-\mathrm{O}(6)-\mathrm{C}(61) & 155.3(6) \\ \mathrm{Y}(2)-\mathrm{O}(1)-\mathrm{C}(11) & 120.1(5) & \mathrm{Na}-\mathrm{O}(4)-\mathrm{C}(41) & 116.3(5) \\ \mathrm{Y}(2)-\mathrm{O}(2)-\mathrm{C}(21) & 118.9(5) & \mathrm{Na}-\mathrm{O}(5)-\mathrm{C}(51) & 118.8(5) \\ \mathrm{Y}(2)-\mathrm{O}(3)-\mathrm{C}(31) & 122.9(5) & \mathrm{Na}-\mathrm{O}(6)-\mathrm{C}(61) & 117.8(6) \\ \mathrm{Cl}-\mathrm{Y}(1) \cdots \mathrm{Y}(2) & 179.36(8) & & \\ \mathrm{Y}(1) \cdots \mathrm{Y}(2) \cdots \mathrm{Na} & 178.38(10) & & \end{array}$

atoms, a six-coordinate pocket for the sodium atom, analogous to the situation observed around $\mathrm{Na}$ in $\mathbf{3 a}$. As a result of the coordination of the amino substituents of the first shell of phenolate ligands to $\mathrm{Y}(1)$ and of those of the second shell to $\mathrm{Na}$, the aromatic planes of the ligands are tilted from a position perpendicular to the $\mathrm{Cl}-\mathrm{Y}(1) \cdots \mathrm{Y}(2) \cdots \mathrm{Na}$ axis, resulting in two staggered shells of three ligands; these shells have screw-type chiralities with opposite sense (see Figure 4). A view along 
Scheme 1. Synthesis and Schematic Representations of 3a and $\mathbf{3 b}$

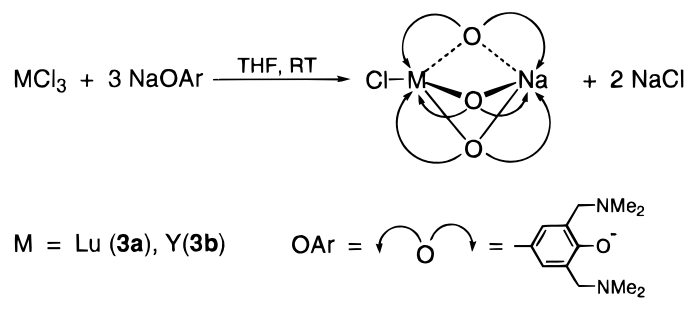

Scheme 2. Synthesis and Schematic Representation of 4

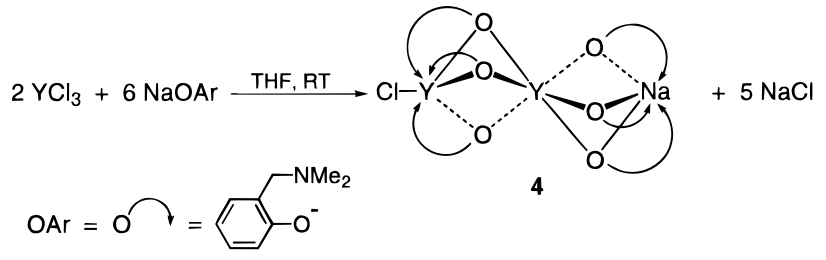

the $\mathrm{Cl}-\mathrm{Y}(1) \cdots \mathrm{Y}(2) \cdots \mathrm{Na}$ pseudo-3-fold axis shows this arrangement (see Figure 5).

Both the $\mathrm{Y}-\mathrm{O}$ bond lengths and the $\mathrm{Y}-\mathrm{O}-\mathrm{C}$ bond angles for 4 can be gathered into three groups, as shown in Figure 6. This figure indicates a near-linear relationship between these structural variables. Combination of these structural data for $\mathbf{4}$ with those of previously reported yttrium phenolate complexes (see Table 6) shows that virtually all the yttrium-phenolate interactions closely follow the trend observed in complex 4 (see Figure 7). The combination of short $\mathrm{Y}-\mathrm{O}$ bond lengths with large $\mathrm{Y}-\mathrm{O}-\mathrm{C}$ bond angles that are observed for terminal phenolate ligands as well as for the phenolate ligands bridging between $\mathrm{Y}$ and $\mathrm{Na}$ in $\mathbf{4}$ (see Figure 7) is relatively common in early-transition metal chemistry and has been explained as resulting from oxygen $\mathrm{p} \pi$ to metal $\mathrm{d} \pi$ interactions. ${ }^{34}$ The only exception to the trend is $\left(\mathrm{C}_{5} \mathrm{Me}_{5}\right) \mathrm{Y}\left(\mathrm{OC}_{6} \mathrm{H}_{3}{ }^{\mathrm{t}} \mathrm{Bu}_{2}-2,6\right)_{2}(\mathbf{1 0}),{ }^{38}$ which contains one yttrium-phenolate interaction that follows the general trend and one that shows an $\mathrm{Y}-\mathrm{O}-\mathrm{C}$ angle that is "abnormally" acute $\left(128.6(3)^{\circ}\right)$ with respect to the short $\mathrm{Y}-\mathrm{O}$ bond length of 2.096(4) $\AA$ (see Figure 7). The reason for this deviation is not clear.

As in complex 3a, one Na-O bond distance in $\mathbf{4}$ is shorter than the other two: 2.557(7) $\AA$ vs 2.660(9) and 2.661(8) $\AA$. These $\mathrm{Na}-\mathrm{O}$ bond distances are much larger than the corresponding distances in $\left[\mathrm{NaOC}_{6} \mathrm{H}_{2}\left(\mathrm{CH}_{2} \mathrm{NMe}_{2}\right)_{2}-2,6-\mathrm{Me}-4\right]_{4}(\mathbf{6}),{ }^{15}$ $(2.325(4)-2.417(2) \AA)$ and indicative of coordinative bonds. The $\mathrm{Na}-\mathrm{N}$ bond lengths $(2.520(17)-2.573(14) \AA$ ) are similar to those in $\mathbf{6}$ and shorter than those in $\mathbf{3 a}$.

As in complex 3a (vide supra), in the crystal packing of $\mathbf{4}$ the yttrium-chloride vector of one residue points to the sodium ion captured in the pocket of the next, to give parallel "head to tail" cylinders $\{(\mathrm{Na} \cdots \mathrm{Y} \cdots \mathrm{Y}-\mathrm{Cl}) \cdots(\mathrm{Na} \cdots \mathrm{Y} \cdots \mathrm{Y}-\mathrm{Cl})\}_{n}$ running through the crystal. The intermolecular distance between the chloride of one unit and the sodium of the next is at 4.153(5)

(34) (a) Coffindaffer, T. W.; Rothwell, I. P.; Huffman, J. C. Inorg. Chem. 1983, 22, 2906. (b) Huffman, J. C.; Moloy, K. G.; Marsella, J. A.; Caulton, K. G. J. Am. Chem. Soc. 1980, 3009. (c) Evans, W. J.; Grate, J. W.; Bloom, I.; Hunter, W. E.; Atwood, J. L. J. Am. Chem. Soc. 1985, 107, 405. (d) Evans, W. J.; Hanusa, T. P.; Levan, K. R. Inorg. Chim. Acta 1985, 110, 191. (e) Chisholm, M. H.; Rothwell, I. P. Comprehensive Coordination Chemistry; Wilkinson, G., Ed.; Pergamon Press: Oxford, England, 1987; Vol. 2, p 351.

(35) Evans, W. J.; Olofson, J. M.; Ziller, J. W. Inorg. Chem. 1989, 28, 4308.

(36) Hitchcock, P. B.; Lappert, M. F.; Smith, R. G. Inorg. Chim. Acta 1987, 139, 183.

(37) Schumann, H.; Winterfeld, J.; Köhn, R. D.; Esser, L.; Sun, J.; Dietrich, A. Chem. Ber. 1993, 126, 907.

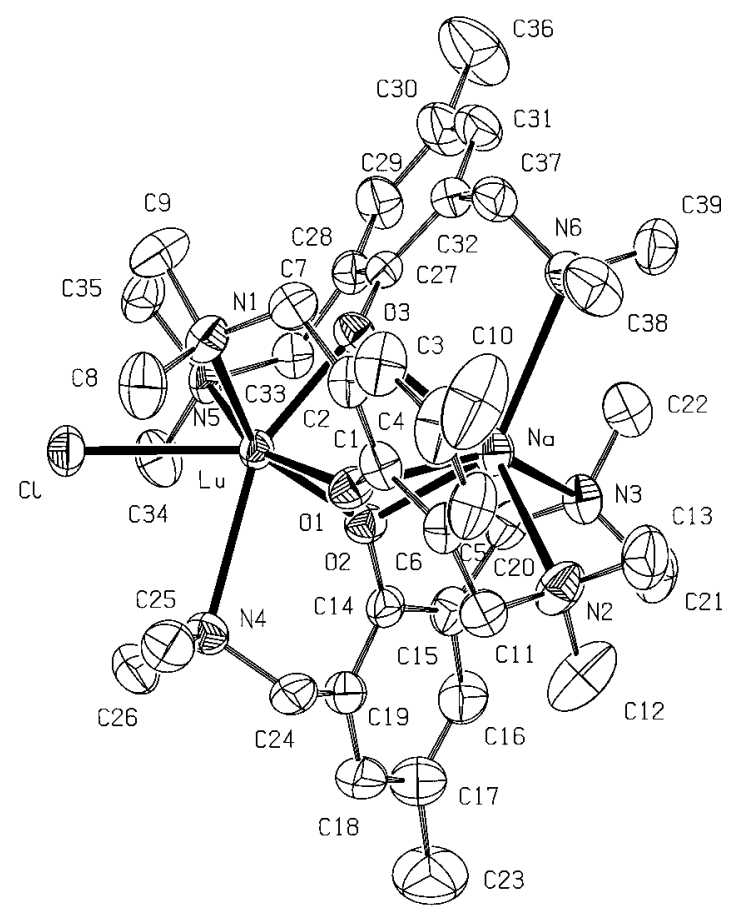

Figure 2. ORTEP drawing (40\% probability) of $\left\{\mathrm{ClLu}\left[\mathrm{OC}_{6} \mathrm{H}_{2}\left(\mathrm{CH}_{2}-\right.\right.\right.$ $\left.\left.\left.\mathrm{NMe}_{2}\right)_{2}-2,6-\mathrm{Me}-4\right]_{3} \mathrm{Na}\right\}$ (3a) with the adopted numbering scheme.

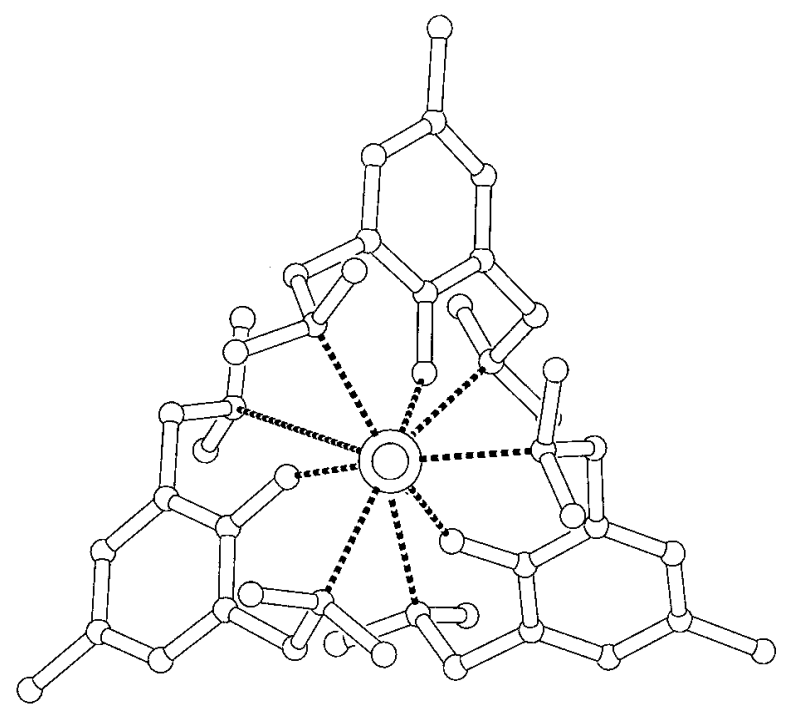

Figure 3. PLUTON drawing of $\left\{\mathrm{ClLu}\left[\mathrm{OC}_{6} \mathrm{H}_{2}\left(\mathrm{CH}_{2} \mathrm{NMe}_{2}\right)_{2}-2,6-\right.\right.$ $\mathrm{Me}-4]_{3} \mathrm{Na}$ (3a) showing the view along the pseudo-3-fold axis $(\mathrm{Cl}$ in front).

$\AA$ smaller than the 4.765(3) $\AA$ found in the crystal packing of 3a, but still much larger than the sum of the covalent radii $(2.53$ $\AA$ ). In contrast to the crystal packing of $\mathbf{3 a}$, where both possible enantiomers are present in the measured crystal, only one of the four possible stereoisomers of $\mathbf{4}$ is present in the measured crystal. The relatively large space around these cylinders is filled with strongly disordered crystal solvent, which could not be modeled in the crystal structure determination.

Structures in Solution. The solid-state structures are retained in solution, as appears from ${ }^{1} \mathrm{H}$ and ${ }^{13} \mathrm{C}$ NMR data. At room temperature the ${ }^{1} \mathrm{H}$ NMR spectrum of $\mathbf{3 a}$ in $\mathrm{C}_{6} \mathrm{D}_{6}$ shows two broad signals for the $\mathrm{NMe}_{2}$ protons and four broad resonances for the benzylic protons. In addition, the ${ }^{13} \mathrm{C} N M R$ in $\mathrm{C}_{6} \mathrm{D}_{6}$ shows two separate resonances for both the benzylic and $\mathrm{NMe}_{2}$ carbon atoms and single resonances for all aromatic carbon atoms. These data indicate that all phenolate ligands are equivalent in solution, with different binding modes for the 


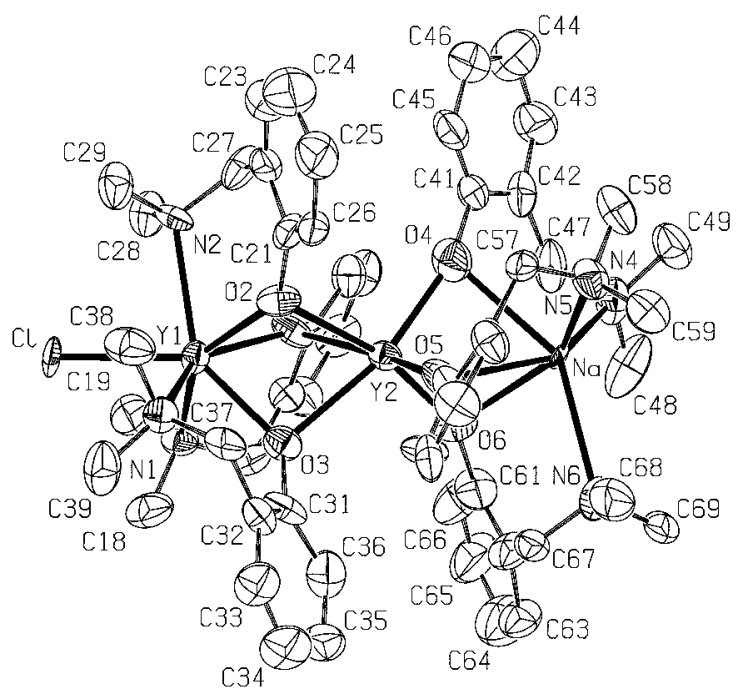

Figure 4. ORTEP drawing (30\% probability) of $\left\{\mathrm{ClY}\left[\mu-\mathrm{OC}_{6} \mathrm{H}_{4}\left(\mathrm{CH}_{2}-\right.\right.\right.$ $\left.\left.\left.\mathrm{NMe}_{2}\right)-2\right]_{3} \mathrm{Y}_{[} \mathrm{OC}_{6} \mathrm{H}_{4}\left(\mathrm{CH}_{2} \mathrm{NMe}_{2}\right)-2\right]_{3} \mathrm{Na}$ \} (4) with the adopted numbering scheme.

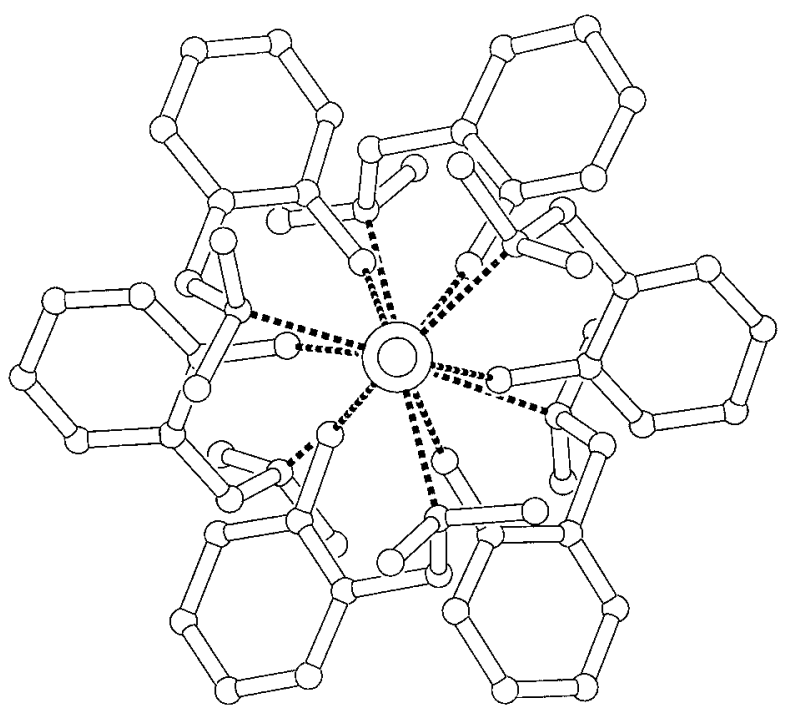

Figure 5. PLUTON drawing of $\left\{\mathrm{CIY}\left[\mu-\mathrm{OC}_{6} \mathrm{H}_{4}\left(\mathrm{CH}_{2} \mathrm{NMe}_{2}\right)-2\right]_{3} \mathrm{Y}\left[\mathrm{OC}_{6} \mathrm{H}_{4}\right.\right.$ $\left.\left(\mathrm{CH}_{2} \mathrm{NMe}_{2}\right)-2\right]_{3} \mathrm{Na}$ \} (4) showing the view along the pseudo-3-fold axis (Cl in front).

two amino substituents. Room temperature NMR data for $\mathbf{3 b}$ are similar, although the signals for the benzylic protons are too broad to be observed. Interestingly, the resonance for the ipso-carbons in $\mathbf{3 b}$ is a doublet due to coupling with ${ }^{89} \mathrm{Y}(100 \%$ abundance $I=1 / 2$ ), with ${ }^{2} J_{\mathrm{YC}}=2.2 \mathrm{~Hz}$. To our knowledge, this is the first time an ${ }^{89} \mathrm{Y}$ coupling has been observed with a phenolate ipso-carbon.

At $-40{ }^{\circ} \mathrm{C}$ in a toluene- $d_{8}$ solution of $\mathbf{3 b}$, the ${ }^{1} \mathrm{H}$ NMR spectrum shows three singlet signals for the $\mathrm{NMe}_{2}$ protons: two integrating for 9 protons each at 1.43 and $1.63 \mathrm{ppm}$, and one integrating for 18 protons at $2.53 \mathrm{ppm}$. The resonances for the benzylic protons appear as two AX patterns with all four doublets integrating for three protons each. This shows that at this temperature the two amino substituents on each phenolate ligand experience different chemical environments (no rotation of the ligand around the $\mathrm{C}-\mathrm{O}$ bond), while the association/ dissociation process of one of the two metal to nitrogen dative bonds is blocked on the NMR time scale. On account of the

(38) Schaverien, C. J.; Frijns, J. H. G.; Heeres, H. J.; van den Hende, J. R.; Teuben, J. H.; Spek, A. L. J. Chem. Soc., Chem. Commun. 1991, 642 .

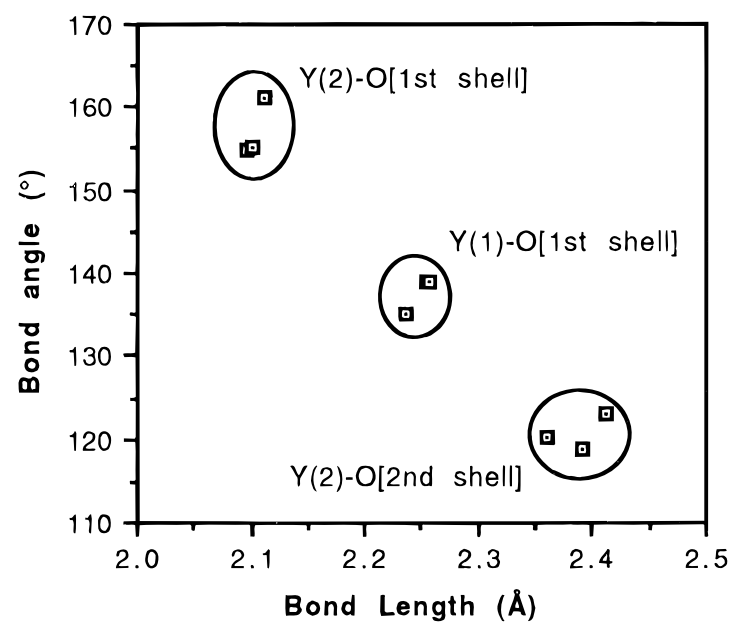

Figure 6. $\mathrm{Y}-\mathrm{O}$ bond length $(\AA)$ vs $\mathrm{Y}-\mathrm{O}-\mathrm{C}$ bond angles for complex 4. In this graph " 1 st shell" refers to the phenolate ligands bridging the two Y-atoms and "2nd shell" to the phenolate ligands bridging $\mathrm{Y}$ and $\mathrm{Na}$ in the molecular structure of $\mathbf{4}$.

Table 6. $\mathrm{Y}-\mathrm{O}$ Bond Lengths and $\mathrm{Y}-\mathrm{O}-\mathrm{C}$ Bond Angles in Yttrium Phenolates

\begin{tabular}{llll}
\hline \multicolumn{1}{c}{ complex } & \multicolumn{1}{c}{$\mathrm{Y}-\mathrm{O}$} & $\mathrm{Y}-\mathrm{O}-\mathrm{C}$ & \\
$(\AA)$ & \multicolumn{1}{c}{$(\mathrm{deg})$} & ref \\
\hline$\left.\left[\mathrm{Y}_{(\mathrm{OC}} \mathrm{H}_{3} \mathrm{Me}_{2}-2,6\right)_{3}(\mathrm{THF})\right]_{2}(\mathbf{7})$ & $2.075(6)$ & $162.6(5)$ & 35 \\
& $2.046(6)$ & $168.7(6)$ & \\
$\mathrm{Y}\left(\mathrm{OC}_{6} \mathrm{H}_{3}{ }^{ } \mathrm{Bu}_{2}-2,6\right)_{3}(\mathbf{8})$ & $2.00(1)$ & $175(1)$ & 36 \\
& $2.00(2)$ & $173(1)$ & \\
& $2.00(1)$ & $171(1)$ & \\
{$\left[\left(\mathrm{C}_{8} \mathrm{H}_{8}\right) \mathrm{Y}\left(\mathrm{OC}_{6} \mathrm{H}_{5}\right)(\mathrm{THF})\right]_{2}(\mathbf{9})$} & $2.360(5)$ & 117.95 & 37 \\
& $2.294(4)$ & 121.09 & \\
& $2.250(5)$ & 135.74 & \\
$\left(\mathrm{C}_{5} \mathrm{Me}_{5}\right) \mathrm{Y}\left(\mathrm{OC}_{6} \mathrm{H}_{3}{ }^{\mathrm{B}} \mathrm{Bu}_{2}-2,6\right)_{2}(\mathbf{1 0})$ & $2.259(4)$ & 130.63 & \\
& $2.096(4)$ & $128.6(3)$ & 38 \\
$\mathrm{Y}_{2} \mathrm{NaCl}\left[\mathrm{OC}_{6} \mathrm{H}_{4}\left(\mathrm{CH}_{2} \mathrm{NMe}_{2}\right)-2\right]_{6}(\mathbf{4})$ & $2.059(3)$ & $154.0(9)$ & \\
& $2.100(6)$ & $155.3(6)$ & this work \\
& $2.096(7)$ & $154.9(5)$ & \\
& $2.111(6)$ & $161.1(6)$ & \\
& $2.255(6)$ & $139.0(5)$ & \\
& $2.236(7)$ & $135.1(5)$ & \\
& $2.256(6)$ & $138.9(6)$ & \\
& $2.360(6)$ & $120.1(5)$ & \\
& $2.391(6)$ & $118.9(5)$ & \\
& $2.411(6)$ & $122.9(5)$ &
\end{tabular}

stronger Lewis acidic character of the yttrium ion as compared to the sodium ion, the activation energy for $\mathrm{Y}-\mathrm{N}$ dissociation can be expected to be higher than that for $\mathrm{Na}-\mathrm{N}$ dissociation and the $\mathrm{Y}-\mathrm{N}$ association/dissociation process will be the first to become slow on the NMR time scale. As a result, the $\mathrm{NMe}_{2}$ resonances at 1.43 and $1.63 \mathrm{ppm}$ can be assigned to the amino substituents coordinated to yttrium. Consequently the $\mathrm{Na}-\mathrm{N}$ dissociation/association process at this temperature is still fast on the NMR time scale, resulting in homotopic resonances.

When the temperature is raised, line broadening and coalescence of the various resonances occurs. At room temperature, the resonances of the benzylic protons are so broad that they are observed with difficulty, while the presence of two broad $\mathrm{NMe}_{2}$ signals show that, although both the $\mathrm{Y}-\mathrm{N}$ and $\mathrm{Na}-\mathrm{N}$ association/dissociation processes have become fast on the NMR time scale, rotation of the ligand around the $\mathrm{C}-\mathrm{O}$ bonds is still slow. At higher temperatures $(343 \mathrm{~K})$, the latter signals also coalesce, which can only be explained by rotation of the $\mathrm{O}$-bonded phenolate ligands around the $\mathrm{C}-\mathrm{O}$ bonds. These observations indicate that both $\mathbf{3 a}$ and $\mathbf{3 b}$ have similar structures with asymmetric $\mathrm{Na}-\mathrm{N}$ and $\mathrm{Y} / \mathrm{Lu}-\mathrm{N}$ bonding of the bis $(o-$ amino)phenolate ligands. 


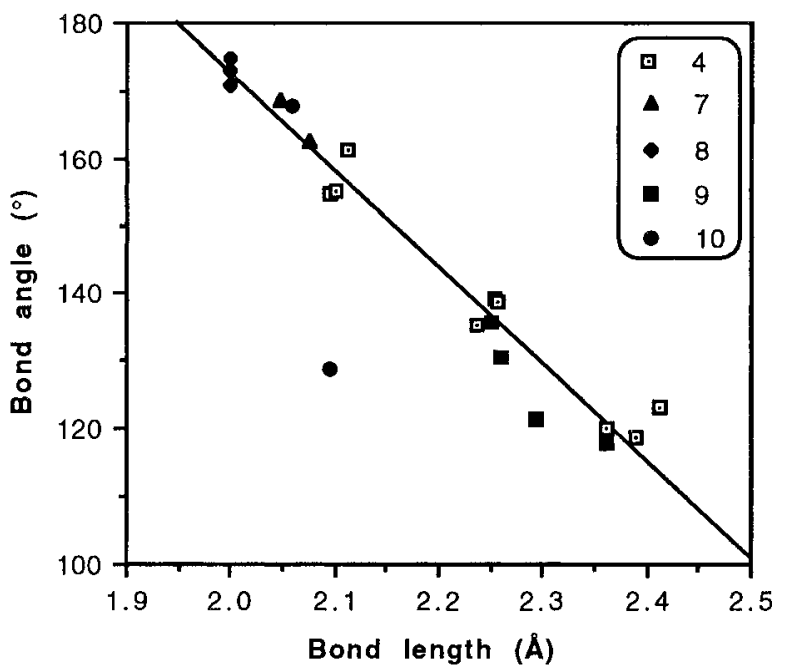

Figure 7. $\mathrm{Y}-\mathrm{O}$ bond lengths vs $\mathrm{Y}-\mathrm{O}-\mathrm{C}$ bond angles for yttrium phenolates. For references and complex numbering see Table 6.

${ }^{1} \mathrm{H}$ and ${ }^{13} \mathrm{C}$ NMR characterization of $\mathbf{4}$ indicates the presence of two different coordination geometries for the phenolate ligand and temperature dependent resonances. The ${ }^{1} \mathrm{H}$ NMR spectrum at room temperature in $\mathrm{CDCl}_{3}$ shows two different $\mathrm{AX}$ patterns for the benzylic protons, while the $\mathrm{NMe}_{2}$ protons give rise to two separate signals (1.99 and $1.94 \mathrm{ppm}$ ) for one coordination geometry and to a single broad signal $(1.62 \mathrm{ppm})$ for the other. Furthermore, the ${ }^{13} \mathrm{C}$ NMR spectrum shows two separate signals for the ipso-carbon (164.24 and $160.01 \mathrm{ppm})$, as well as two separate resonances for the benzylic carbon atom and three for the $\mathrm{NMe}_{2}$ carbons. The presence of two separate resonances for the $\mathrm{NMe}_{2}$ hydrogen and carbon atoms for one of the two coordination geometries and a single resonance for the other shows that the association/dissociation process for the nitrogen to metal dative bond is slow on the NMR time scale for the former and fast for the latter. Using the same argument as mentioned above for $\mathbf{3 b}$, the fast association/dissociation process can be assigned to the $\mathrm{Na}-\mathrm{N}$ dative bonds. In addition, the NMR data show that exchange between the two coordination geometries does not take place on the NMR time scale. Also here, the resonances for the ipso-carbons both appear as doublets due to coupling with ${ }^{89} \mathrm{Y}$ : the signal at $164.24 \mathrm{ppm}$ shows a coupling of $4.0 \mathrm{~Hz}$ and the signal at 160.01 a coupling of 0.6 $\mathrm{Hz}$. In addition to this, the ${ }^{1} \mathrm{H}$ NMR spectrum shows a doublet for one aromatic proton that is shifted considerably upfield (5.80 ppm).

Cooling a $\mathrm{CDCl}_{3}$ solution of 4 to $238 \mathrm{~K}$ slows the association/ dissociation process of the nitrogen dative bonds (further) down, causing also the broad singlet at $1.62 \mathrm{ppm}$ in the ${ }^{1} \mathrm{H}$ NMR spectrum to split up into two separate signals (1.58 and 1.78 ppm). All other resonances remain unchanged. Raising the temperature to $330 \mathrm{~K}$ in $\mathrm{CDCl}_{3}$ only leads to coalescence of the set of signals for the $\mathrm{NMe}_{2}$ group of one coordination geometry at 1.58 and $1.78 \mathrm{ppm}$. The two AX patterns for the benzylic protons are still present in the ${ }^{1} \mathrm{H}$ NMR at $330 \mathrm{~K}$, as well as the two separate signals for the $\mathrm{NMe}_{2}$ group of the other coordination geometry. This shows the rigid nature of the structure of $\mathbf{4}$.

${ }^{89} \mathbf{Y}$ NMR. ${ }^{89} \mathrm{Y}$ NMR spectra of $3 \mathbf{b}$ in $\mathrm{C}_{6} \mathrm{D}_{6}$ at room temperature show a single, broad resonance at $160.9 \mathrm{ppm}$ relative to $3 \mathrm{M} \mathrm{YCl}_{3}$ in $\mathrm{D}_{2} \mathrm{O}$. Raising the temperature to 325 $\mathrm{K}$ led to considerable sharpening of the signal.

As a result of the negative NOE effect of ${ }^{89} \mathrm{Y}$, a considerable (negative) ${ }^{89} \mathrm{Y}$ signal enhancement was observed for $\mathbf{4}$ on using the decoupler. ${ }^{89} \mathrm{Y}$ spectra (H-decoupled) of $\mathbf{4}$ show two sharp

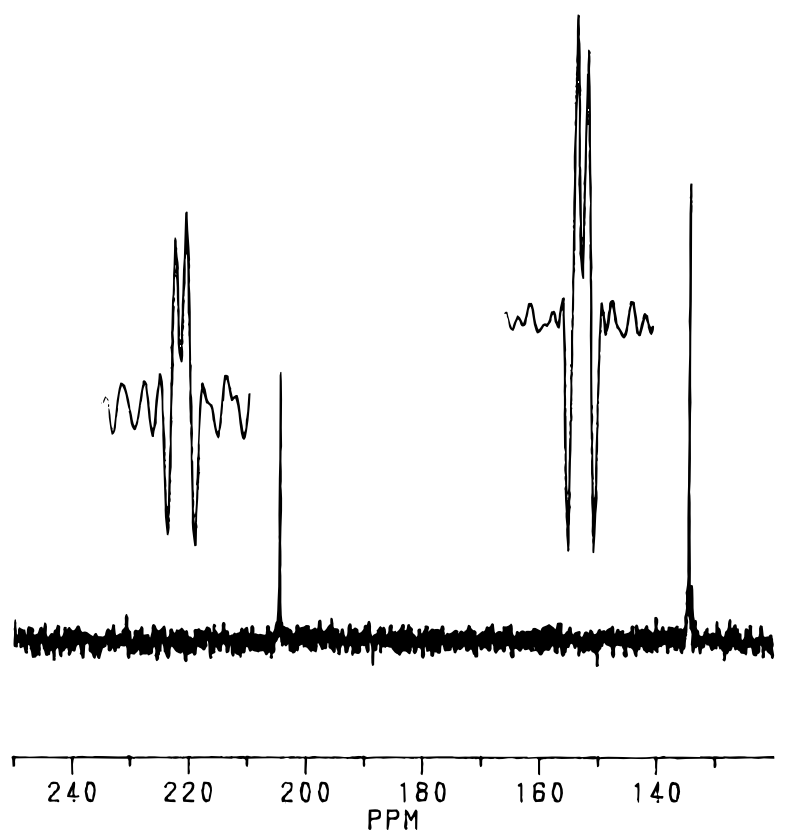

Figure 8. ${ }^{89} \mathrm{Y}$ NMR spectrum of $\mathbf{4}$ in $\mathrm{CDCl}_{3}(1.5 \mathrm{M}$; H-decoupled; 40 transients): coupling structure obtained by increasing the number of data points from $16 \mathrm{~K}$ to $132 \mathrm{~K}$ followed by a Gaussian Fourier procedure.

resonances at 132.4 and $202.4 \mathrm{ppm}$, both appearing as doublets due to coupling with each other, with ${ }^{2} J_{\mathrm{YY}}=0.4 \mathrm{~Hz}$ (see Figure 8). This indicates that the molecular structure of $\mathbf{4}$ in solution also comprises two inequivalent yttrium atoms, while the presence of the ${ }^{89} \mathrm{Y}^{89} \mathrm{Y}$ spin-spin coupling confirms that the number of connecting bonds is small, which correlates with the bridging phenolate ligands observed in the solid state structure. When the decoupler is not used, the signal at $202.4 \mathrm{ppm}$ becomes broader and some extra, poorly resolved fine structure becomes visible; i.e., this signal is coupled to an indeterminate number of protons; the signal at $132.4 \mathrm{ppm}$ remains relatively sharp.

The assignment to the individual yttrium atoms of the two resonances observed by ${ }^{89} \mathrm{Y}$ NMR for $\mathbf{4}$ remains, however, a problem. The additional coupling structure, observed on the ${ }^{89} \mathrm{Y}$ signal at $202.4 \mathrm{ppm}$ when the decoupler was not used, can be a result of (i) coupling of the $\mathrm{NMe}_{2}$ protons of the ligands in the first shell with Y(1) or (ii) coupling of the aromatic orthoprotons of the ligands in both shells with $\mathrm{Y}(2)$. An attempt to obtain further experimental data by a 2D Y-H correlation NMR experiment was unsuccessful. In addition, the ${ }^{89} \mathrm{Y}$ chemical shift of 160.9 ppm found for $\mathbf{3 b}$ falls in between the two signals found for 4 (202.4 and $132.4 \mathrm{ppm}$ ) and does not provide additional information with respect to the assignment of the two ${ }^{89} \mathrm{Y}$ signals of 4 .

As stated earlier, based on the solid state structure, in principle four stereoisomers of $\mathbf{4}$ are possible, while the NMR spectra ${ }^{1} \mathrm{H},{ }^{13} \mathrm{C}$ and $\left.{ }^{89} \mathrm{Y}\right)$ only show one set of signals. These four stereoisomers can be divided into two enantiomeric pairs: (i) one pair where the two shells of screw-type chirality are of opposite sign (MP/PM pair) and (ii) one pair where they are of equal sign (MM/PP pair). ${ }^{1} \mathrm{H}$ and ${ }^{13} \mathrm{C} \mathrm{NMR}$, both at room temperature and below room temperature, show a single set of signals for 4 , indicating that only one of the two enantiomeric pairs is present in solution. Connected to this is the presence of a doublet for one aromatic ortho-proton in the ${ }^{1} \mathrm{H}$ NMR spectrum of 4 , which is shifted considerably upfield at $5.80 \mathrm{ppm}$, and a second one that is shifted slightly upfield at $6.51 \mathrm{ppm}$. In the solid state structure of either MP or PM, the aromatic ortho- 
Scheme 3. Cooperativity in Anion-Cation Bonding

Leading to the Formation of $\mathbf{3 a}$ and $\mathbf{3 b}$

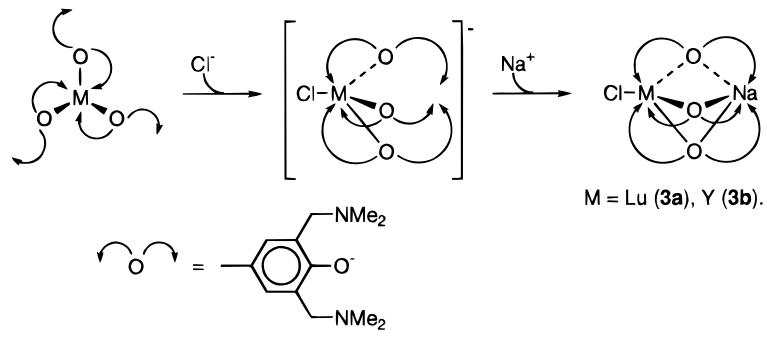

proton of a ligand in the second shell is, as a result of the opposite signs of screw-type chirality, positioned in the shielding cone of the aromatic ring of a ligand in the first shell and vice versa. The average distance to the aromatic ring is 3.045(11) $\AA$ in the former case, while it is much longer at an average of 3.36(9) $\AA$ in the latter. This increased shielding of the orthoprotons would not be present in MM or PP, leading to the conclusion that also in solution only the MP/PM pair is present. This is to be expected, since steric repulsion between the aromatic rings in the separate shells is likely to be more pronounced in the MM/PP pair than in the MP/PM pair and the latter pair is therefore preferred.

The fact that the ${ }^{1} \mathrm{H}$ NMR spectra of the mono(o-amino)phenolate complex 4 hardly show fluxional behavior of the complex in solution (only for the amino substituents coordinated to sodium is the coalescence temperature below $330 \mathrm{~K}$ ), is in contrast to the fluxional behavior of the bis (o-amino) complexes 3a and 3b (all coalescence temperatures are at $343 \mathrm{~K}$ or below). This may be explained by the staggered arrangement of the two shells of phenolate ligands in 4 . In combination with the opposite signs of screw-type chirality this forms a rigid arrangement where rotation of any one ligand can occur only with simultaneous rotation, in the same direction, of all ligands (transition from PM to MP or vice versa). In addition, it may even be necessary for all nitrogen dative bonds to be dissociated for this transition between the two enantiomers to take place. As may be expected, this process is of high energy and therefore slow on the NMR time scale, as evidenced by the presence of the AX patterns for the benzylic protons even at $330 \mathrm{~K}$.

\section{Discussion}

The bis(o-amino) complexes $\mathbf{3}$ and $\mathbf{4}$ are "ate" complexes with structural features that have not been previously observed. The process of formation of $\mathbf{3}$ and $\mathbf{4}$ can be described in terms of cooperative anion-cation bonding. In detail, the structure of 3a can be thought of as starting from a lutetium tris(phenolate), $\mathrm{Lu}\left[\mathrm{OC}_{6} \mathrm{H}_{2}\left(\mathrm{CH}_{2} \mathrm{NMe}_{2}\right)_{2}-2,6-\mathrm{Me}-4\right]_{3}$, which is sixcoordinate on account of the rigidity of the ligand systems. Coordination of chloride anion completes the coordination sphere around lutetium, leading to preorganization of the three remaining pendant amino-substituents (see Scheme 3) and formation of an organized $\mathrm{N}_{3} \mathrm{O}_{3}$ pocket. Due to the negative charge on the oxygen centers this pocket is able to positively bind the sodium cation. This cooperativity in anion-cation bonding can be seen as a result of the "excess" coordinating capability present in the bis(o-amino) substituted phenolate ligand.

A somewhat similar self-assembling process has very recently been reported for the nickel(II) complex of 3-methoxysalicylaldimine $\left(\mathrm{L}^{2}\right),\left(\mathrm{L}^{2}\right)_{2} \mathrm{Ni}$, in which the trans $-\mathrm{NiN}_{2} \mathrm{O}_{2}$ chromophore in the monometallic complex changes its configuration to $\mathrm{cis}$ upon the addition of lithium, sodium or potassium salts. This change in the donor atom arrangement of the two ligands around
Scheme 4. Self-Assembly of Complex 4 through Positive Cooperativity in Anion-Cation Bonding

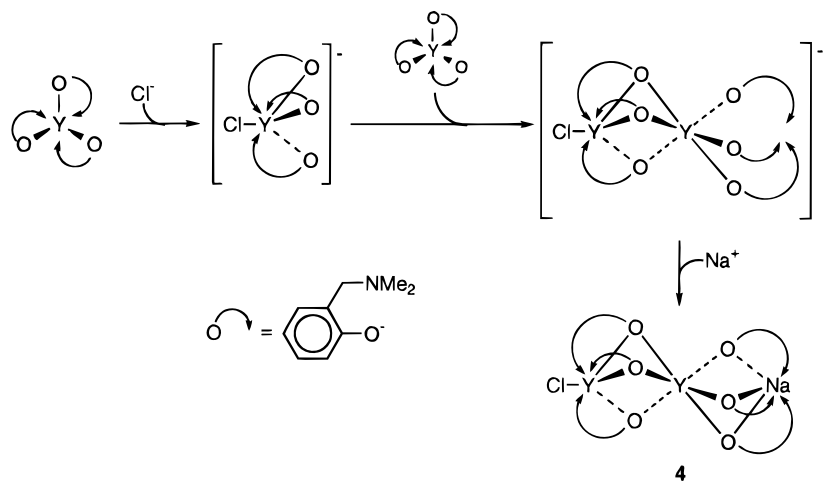

the nickel center results in the formation of an outer $\mathrm{O}_{4}$ pocket that is able to bind an alkali metal anion, reminescent of the preorganization of the $\mathrm{N}_{3} \mathrm{O}_{3}$ pocket in the complexes 3 and complex $4 .{ }^{39}$

When the mono(o-amino) substituted phenolate $\mathbf{1}$ is used instead of the bis(o-amino) substituted 2, the three pendant amino substituents, necessary to form the six-coordinate pocket for the sodium ion, are absent. However, from the solid state structure (see Figure 4), it can be seen that preorganization of the three phenolate ligands by coordination of chloride anion to a neutral, coordinatively unsaturated tris(phenolate) moiety $\mathrm{Y}\left[\mathrm{OC}_{6} \mathrm{H}_{4}\left(\mathrm{CH}_{2} \mathrm{NMe}_{2}\right)-2\right]_{3}$ (see Scheme 4), leads to a coordination geometry around $\mathrm{Y}(1)$ in $\mathbf{4}$ that is strikingly similar to the coordination geometry around $\mathrm{Lu}$ in 3a. Coordination of a second tris(phenolate) $\mathrm{Y}\left[\mathrm{OC}_{6} \mathrm{H}_{4}\left(\mathrm{CH}_{2} \mathrm{NMe}_{2}\right)-2\right]_{3}$ to the preorganized arrangement of phenolate oxygen atoms of the $\{\mathrm{ClY}-$ $\left.\left[\mathrm{OC}_{6} \mathrm{H}_{4}\left(\mathrm{CH}_{2} \mathrm{NMe}_{2}\right)-2\right]_{3}\right\}^{-}$moiety precludes the coordination of the amino-substituents of this second shell of phenolate ligands to the second yttrium atom (see coordination geometry around $\mathrm{Y}(2)$ in 4). Then, as a result of the preorganized arrangement of the three phenolate ligands in the $\left\{\mathrm{ClY}\left[\mathrm{OC}_{6} \mathrm{H}_{4}\left(\mathrm{CH}_{2} \mathrm{NMe}_{2}\right)\right.\right.$ $\left.2]_{3}\right\}^{-}$moiety, the three phenolate ligands of the second shell are preorganized to form a $\mathrm{N}_{3} \mathrm{O}_{3}$ pocket. As a result of the negative charge of the resulting bimetallic complex, this $\mathrm{N}_{3} \mathrm{O}_{3}$ pocket is able to positively bind the sodium cation, resulting in a coordination geometry around sodium in $\mathbf{4}$ that closely resembles that in $\mathbf{3 a}$.

This view that the second yttrium atom (Y(2) in the molecular structure of 4, see Figure 4) coordinates to the preorganized arrangement of the three phenolate ligands around Y(1) explains the asymmetric nature of the phenolate bridges and thus the very acute $\mathrm{Y}(2)-\mathrm{O}-\mathrm{C}$ bond angles and long $\mathrm{Y}(2)-\mathrm{O}$ bond lengths connected with the ligands in the first shell. In addition, it allows for the sense of screw-type chirality of the second shell of ligands to be determined by the sense of screw-type chirality of the first shell of ligands, leading to the exclusive formation of the PM/MP enantiomeric pair as observed by NMR (vide supra). This shows that $\mathbf{4}$ is the result of the self-assembly of two different molecules, where the stereochemical information in one building block determines the overall stereochemistry of the resulting polymetallic structure.

The striking structural similarities between the coordination geometries around $\mathrm{Lu}$ in $\mathbf{3 a}$ and $\mathrm{Y}(1)$ in $\mathbf{4}$, as well as around $\mathrm{Na}$ in both complexes, indicate that these geometries are very stable and we propose that the positive cooperativity in anion-cation bonding can be seen as the driving force for the self-assembly of complex $\mathbf{4}$. Furthermore, $\mathbf{4}$ can be seen as comprising the capping ends of an organometallic polymeric

(39) Costes, J.-P.; Dahan, F.; Laurent, J.-P. Inorg. Chem. 1994, 33, 2738. 


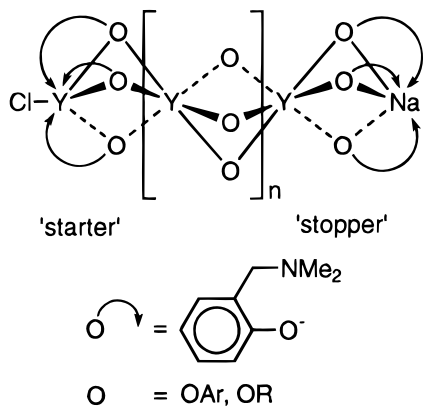

Figure 9. Schematical representation of an organometallic polymer that might be build up from the capping ends that together form complex 4.

material: $\quad\left\{\mathrm{YCl}\left[\mathrm{OC}_{6} \mathrm{H}_{4}\left(\mathrm{CH}_{2} \mathrm{NMe}_{2}\right)-2\right]_{3}\right\}^{-}$(starter) and $\{\mathrm{Y}-$ $\left.\left[\mathrm{OC}_{6} \mathrm{H}_{4}\left(\mathrm{CH}_{2} \mathrm{NMe}_{2}\right)-2\right]_{3} \mathrm{Na}\right\}^{+}$(stopper) for polymeric materials of general formula $\left\{\mathrm{YCl}\left[\mathrm{OC}_{6} \mathrm{H}_{4}\left(\mathrm{CH}_{2} \mathrm{NMe}_{2}\right)-2\right]_{3}\right\}^{-}\left[\mathrm{Y}(\mathrm{OAr})_{3}\right]_{\mathrm{n}^{-}}$ $\left\{\mathrm{Y}_{0}\left[\mathrm{OC}_{6} \mathrm{H}_{4}\left(\mathrm{CH}_{2} \mathrm{NMe}_{2}\right)-2\right]_{3} \mathrm{Na}\right\}^{+}$(see Figure 9).

Design of these complexes involves the insertion of one or more shells of an yttrium tris(alkoxide) or tris(phenolate) complex $\mathrm{Y}(\mathrm{OR})_{3}$ ("spacers") in between the starter and stopper; see Figure 9. In this respect, the use of phenolate complexes is especially interesting, as the screw-type chirality of both starter and stopper will induce screw-type chirality in the spacers, most probably resulting in rigid, rodlike coordination polymers. In principle it may even be possible to insert complexes of metals other than yttrium. Strategies to achieve this goal are currently being studied. Preliminary results of an experiment where complex 4 was mixed, in THF solution, with 1 equiv of $\mathrm{Y}\left(\mathrm{OC}_{6} \mathrm{H}_{3} \mathrm{Me}_{2}-2,6\right)_{3}(\mathrm{THF})_{3}(7)^{35}$ indicate that 1 equiv of $\mathrm{NaCl}$ is liberated with the formation of an as yet unidentified (polymetallic) yttrium complex. So far we have not been able to grow crystals suitable for an X-ray structure determination.

With respect to the preparation of preceramic mixed-metal complexes, the cooperativity in the bonding of anion and cation, resulting in the complexes $\mathbf{3}$ and $\mathbf{4}$, opens the possibility to incorporate cations other than $\mathrm{Na}^{+}$, either by exchange of the cation in the complexes after their preparation or by starting from the neutral metal tris(phenolates) and reacting these with the desired metal salt. Following the former strategy, attempts to substitute the chloride in both $\mathbf{3}$ and $\mathbf{4}$ with phenolate $\left(\mathrm{OC}_{6} \mathrm{H}_{5}\right)$, alkoxide (OiPr, OTf), or alkyl $\left(\mathrm{CH}_{2} \mathrm{SiMe}_{3}, \mathrm{CH}_{3}\right)$ monoanionic ligands either led to isolation of starting products (in the case of $\mathrm{OC}_{6} \mathrm{H}_{5}$ ) or to an undefined reaction mixture (all other attempts). These experiments, however, indicated that the use of lithium reagents to substitute the chloride leads to partial exchange of $\mathrm{Na}^{+}$by $\mathrm{Li}^{+}$. In this respect it is interesting to note that the EI-MS spectrum of $\mathbf{3 b}$ shows the highest mass peak at $776 \mathrm{~m} / \mathrm{z}$, which corresponds to $\mathrm{Na}\left[\mathrm{M}\left(\mathrm{OC}_{6} \mathrm{H}_{4}\left(\mathrm{CH}_{2} \mathrm{NMe}_{2}\right)-2\right)_{3}\right]^{+}$, suggesting that, apart from a relative volatility of the complex, loss of Cl-anion from the molecular ion does lead to a stable cation.

In conclusion, $\mathbf{3 a}, \mathbf{3 b}$, and $\mathbf{4}$ are unique complexes showing the versatility in coordination geometry of the applied monoor bis $\left(o-\mathrm{CH}_{2} \mathrm{NMe}_{2}\right)$-substituted phenolate ligands. The complexes open new perspectives for both the preparation of preceramic (hetero)polymetallic complexes for high temperature superconductor research and the design of self-assembling organometallic materials. In order to test the postulated cooperativity in anion-cation bonding, we are currently developing methods for the preparation of the salt-free $\mathrm{Ln}(\mathrm{OAr})_{3}$ complexes. Such complexes may also be useful for the selective complexation and activation of Lewis bases, since the site on the metal center, which in both $\mathbf{3}$ and $\mathbf{4}$ is occupied by a chloride anion, can in principle be tuned by binding different types of cations in the $\mathrm{N}_{3} \mathrm{O}_{3}$ cavity at the other side of the molecule.

Acknowledgment. This work was financially supported (M.P.H.) by the Innovation Oriented Research Program on Catalysis (IOP-Katalyse) and supported in part (A.L.S. and W.J.J.S.) by the Netherlands Foundation for Chemical Research (SON) with financial aid from the Netherlands Organization for Scientific Research (NWO).

Supporting Information Available: Tables giving further details on the structure determinations, including crystallographic data, atomic coordinates, bond lengths and angles, and thermal parameters for 3a and 4 (12 pages). Ordering information is given on any current masthead page.

IC950639H 